\title{
Synapsin I Is an Oligomannose-Carrying Glycoprotein, Acts As an Oligomannose-Binding Lectin, and Promotes Neurite Outgrowth and Neuronal Survival When Released via Glia-Derived Exosomes
}

\author{
Shiwei Wang, ${ }^{1,4}$ Fabrizia Cesca, ${ }^{2}$ Gabriele Loers, ${ }^{1}$ Michaela Schweizer, ${ }^{1}$ Friedrich Buck, ${ }^{3}$ Fabio Benfenati, ${ }^{2}$ \\ Melitta Schachner, ${ }^{1,5,6}$ and Ralf Kleene ${ }^{1}$ \\ ${ }^{1}$ Zentrum für Molekulare Neurobiologie, Universitätsklinikum Hamburg-Eppendorf, 20246 Hamburg, Germany, ${ }^{2}$ Department of Neuroscience and Brain \\ Technologies, The Italian Institute of Technology, 16163 Genova, Italy, ${ }^{3}$ Institut für Klinische Chemie, Universitätsklinikum Hamburg-Eppendorf, 20246 \\ Hamburg, Germany, ${ }^{4}$ Department of Physiology, Dalian Medical University, Dalian, 116044 China, ${ }^{5}$ Keck Center for Collaborative Neuroscience and \\ Department of Cell Biology and Neuroscience, Rutgers University, Piscataway, New Jersey 08854, and ${ }^{6}$ Center for Neuroscience, Shantou University Medical \\ College, Shantou 515041, China
}

Oligomannosidic glycans play important roles in nervous system development and function. By performing a phage display screening with oligomannose-specific antibodies, we identified an oligomannose-mimicking peptide that was functionally active in modulating neurite outgrowth and neuron-astrocyte adhesion. Using the oligomannose-mimicking peptide in crosslinking experiments, synapsin I was identified as a novel oligomannose-binding protein in mouse brain. Further analyses not only verified that synapsin I is an oligomannose-binding lectin, but also indicated that it is a glycoprotein carrying oligomannose and Lewis ${ }^{\mathrm{x}}$. We also found that synapsin I is expressed in glia-enriched cultures and is released from glial cells via exosomes. Incubation of glial-derived exosomes in the presence of high $\mathrm{KCl}$ concentrations or subjecting glial cell cultures to either oxygen/ glucose deprivation or hydrogen peroxide resulted in release of synapsin I from exosomes. Application of synapsin I promoted neurite outgrowth from hippocampal neurons and increased survival of cortical neurons upon hydrogen peroxide treatment or oxygen/glucose deprivation. Coculture experiments using wild-type hippocampal neurons and wild-type or synapsin-deficient glial cells showed enhanced neurite outgrowth when synapsin was expressed by glial cells. Synapsin-induced neurite outgrowth was dependent on oligomannose on synapsin I and the neural cell adhesion molecule NCAM at the neuronal cell surface. The data indicate that, under conditions of high neuronal activity and/or oxidative stress, synapsin can be released from glial-derived exosomes and promotes neurite outgrowth and neuronal survival by modulating the interactions between glia and neurons.

\section{Introduction}

$\mathrm{N}$-linked oligomannosidic glycans play important roles in modulating nervous system development and function (for review, see Kleene and Schachner, 2004). Oligomannosidic glycans are particularly abundant in the brain, are carried by adhesion molecules such as L1, NCAM, and AMOG (adhesion molecule on glia), are present on both NMDA and AMPA subtypes of glutamate receptors, and are

Received Dec. 13, 2010; revised March 16, 2011; accepted March 25, 2011.

Author contributions: F. Benfenati, M. Schachner, and R.K. designed research; S.W., F.C., G.L., M. Schweizer, F. Buck, and R.K. performed research; F.C., G.L., F. Buck, and R.K. analyzed data; F. Benfenati, M. Schachner, and R.K. wrote the paper.

M.S. is supported by the New Jersey Commission for Spinal Cord Research and is a consultant at the Center for Neuroscience at Shantou University Medical College, China. We are grateful to Ute Bork, Sönke Hader, and Chudamani Raithore for excellent technical assistance, Drs. Paul Greengard (The Rockefeller University, New York, NY) and Hung-Teh Kao (Brown University, Providence, RI) for providing the synapsin TKO mouse strain, Marina Nanni for cell culture, Eva Kronberg for excellent animal care, Claus Schafer-Nielsen (Copenhagen, Denmark) for synthetic peptides, and the Deutsche Forschungsgemeinschaft for support (KL-1378/1-1 and /1-2).

Correspondence should be addressed to Melitta Schachner, Zentrum für Molekulare Neurobiologie, Universitäts klinikum Hamburg, Martinistrasse 52, D-20246 Hamburg, Germany. E-mail: melitta.schachner@ zmnh.uni-hamburg.de.

DOI:10.1523/JNEUROSCI.6476-10.2011

Copyright $\odot 2011$ the authors $\quad 0270-6474 / 11 / 317275-16 \$ 15.00 / 0$ concentrated at presynaptic and postsynaptic membranes of glutamatergic synapses of adult brains (for review, see Kleene and Schachner, 2004). Analysis of oligomannoses isolated from synaptosomes showed that the amount of the two major glycans containing five (man5) and eight (man8) mannoses increases during development with man5 being the predominant form in adult brain (Fu and Gurd, 1983). Oligomannoses also play a role in long-term potentiation of mouse hippocampal neurons (Lüthl et al., 1994) and in regeneration of retinotectal projections in goldfish (Schmidt and Schachner, 1998).

Proteins that bind these oligomannoses as oligomannosebinding lectin-like proteins are the cell adhesion molecules NCAM and basigin (Horstkorte et al., 1993; Heller et al., 2003). Basigin, which is an important player in neuron-glia interactions and in the formation and/or maintenance of the blood-brain barrier, promotes outgrowth of astrocytic processes in an oligomannosedependent manner (Heller et al., 2003). The interaction of NCAM with $\mathrm{L} 1$ depends on oligomannoses on $\mathrm{L} 1$, and disturbance of this oligomannose-dependent interaction reduces L1-induced neurite outgrowth (Horstkorte et al., 1993).

Due to their importance in the nervous system, we further investigated the role of oligomannoses in mediating or modulat- 
ing neural cell adhesion with the intention to identify novel oligomannose-carrying and oligomannose-recognizing proteins from mouse brain. Because of the limited sources of natural oligomannosidic glycans and difficulty in chemical synthesis, it was necessary to use surrogates that structurally and functionally mimic the oligosaccharides. Here, an oligomannose-mimicking peptide was identified by screening a phage display peptide library using two monoclonal oligomannose-specific antibodies (Kücherer et al., 1987; Fahrig et al., 1990). This peptide was then used to identify oligomannose-binding proteins, and synapsin I (hereafter called synapsin) was identified by this approach.

Synapsin is expressed in nervous tissue of vertebrates and invertebrates (Kao et al., 1999; Candiani et al., 2010) and is a neuron-specific, synaptic vesicle-associated protein implicated in neural development (Fornasiero et al., 2010) and synaptic transmission (Cesca et al., 2010). However, some degree of synapsin expression was also found in cultured astrocytes (Maienschein et al., 1999), epithelial cells (Bustos et al., 2001), pancreatic $\beta$ cells (Krueger et al., 1999), and several cell lines of neural and endocrine origin (Romano et al., 1987; Tooze et al., 1989; Matsumoto et al., 1995).

Here, we show that synapsin is a glycoprotein and an oligomannose-binding lectin that modulates neurite outgrowth in an oligomannose- and NCAM-dependent manner. Furthermore, we provide evidence that glial cells express synapsin and release it via exosomes. Synapsin released from exosomes under distinct conditions such as neuronal activity, oxidative stress, and/or ischemia can modulate neuronal outgrowth and neuronglia interactions.

\section{Materials and Methods}

Antibodies and reagents. Monoclonal antibodies L3 and L4 recognizing oligomannosidic glycans were prepared as described previously (Fahrig et al., 1990). The antibodies recognizing Lewis ${ }^{\mathrm{x}}$ (L5), polysialic acid (735), or HNK-1 (412, HNK-1) have been described previously (for references, see Kleene and Schachner, 2004). The commercially available antibodies directed to the following proteins were used: Alix, flotillin, and PDI from BD Transduction Laboratories; GAPDH and myelin basic protein from Millipore; calreticulin, hsc70, and 14-3-3 from Santa Cruz Biotechnology; synapsin and synaptophysin from Synaptic Systems; phosphorylated neurofilament heavy chain (SMI-310R) from Covance; Iba-1 from Wako; neuronal class III $\beta$-tubulin (T2200) and actin from Sigma-Aldrich. Synthetic peptides were obtained from Schafer-N and RNase B from Sigma-Aldrich. Synapsin was purified from calf brain under non-denaturing conditions and antibodies against synapsin were prepared as previously described (Bähler and Greengard, 1987). AMOG was prepared from mouse brain by affinity chromatography using AMOG-specific monoclonal antibodies as described previously (Antonicek and Schachner, 1988). The extracellular domain of NCAM fused to the Fc fragment of human IgG (NCAM-Fc) and the extracellular domain of the close homolog of L1 (CHL1) fused to the Fc fragment $(\mathrm{CHL} 1-\mathrm{Fc})$ were prepared and purified as described previously (Chen et al., 1999; Schmid et al., 1999). Endoglycosidase H (EndoH) and peptidyl$N$-glycosidase F (PNGase F) were purchased from Roche Diagnostics. NCAM-deficient mice (Cremer et al., 1994) and C57BL/6 mice were bred and maintained at the animal facility of the Universitätsklinikum Hamburg-Eppendorf. Mice of either sex were used.

Screening of phage display peptide library. The antibodies L3 and L4 (10 $\mu \mathrm{g}$ ) were immobilized on $0.5 \mathrm{mg}$ of magnetic Dynabeads M 270 (Dynal Biotech), followed by blocking with $0.5 \%$ bovine serum albumin (BSA) in $0.1 \mathrm{~m}$ sodium phosphate buffer, $\mathrm{pH}$ 7.4. The Ph.D.-12 Phage Display Peptide Library Kit (New England Biolabs) was used to express linear random 12-mer peptides fused to the N terminus of M13 coat protein PIII. Three rounds of panning were performed as described previously (Simon-Haldi et al., 2002). Briefly, $4 \times 10^{10}$ phages were incubated with beads carrying L 3 and L4 antibodies for $30 \mathrm{~min}$ at room temperature, and beads were washed 10 times with $1 \mathrm{ml}$ of Tris-buffered saline (TBS; $\mathrm{pH}$ 7.4 ) containing $0.1 \%, 0.3 \%$, and $0.5 \%(\mathrm{v} / \mathrm{v})$ Tween 20 in the first, second, and third rounds of panning, respectively. In each round of panning, phages were eluted using either L3 or L4 antibodies ( $10 \mu \mathrm{g}$ in $100 \mu \mathrm{l}$ of TBS) or oligomannoses ( $5 \mu \mathrm{g}$ in $100 \mu \mathrm{l}$ of TBS) isolated from RNase B after EndoH treatment. Eluted phages were amplified and $2 \times 10^{11}$ amplified phages were applied for panning in the second and third rounds. After three rounds of panning, individual phage clones were isolated and single-stranded phage DNA was purified and subjected to DNA sequencing to determine the peptide sequences expressed by the phages.

Conjugation of synthetic peptides to catalase. Synthetic peptides bearing a cysteine residue at the $\mathrm{C}$ terminus were coupled to catalase (SigmaAldrich) using the crosslinker $m$-maleimido-benzoyl- $N$-hydroxy-succinimidyl ester (MBS; Pierce Biotechnology). Catalase (0.1 mM) dissolved in 0.9 $\mathrm{ml}$ of conjugation buffer (5 mM EDTA in PBS, pH 7.2) was mixed with $1 \mathrm{~mm}$ MBS freshly dissolved in $0.1 \mathrm{ml}$ of dimethyl sulfoxide (DMSO). After $30 \mathrm{~min}$ incubation at room temperature, unbound MBS was removed by gel filtration through a PD-10 column (GE Healthcare). The flow-through was incubated with $1 \mathrm{~mm}$ peptides freshly dissolved in $0.2 \mathrm{ml}$ of $20 \%$ DMSO in PBS. This mixture was incubated at room temperature for $30 \mathrm{~min}$, dialyzed overnight at $4^{\circ} \mathrm{C}$ against $4 \mathrm{~L}$ of TBS, and concentrated by Vivaspin concentrators (Vivaspin 20, Vivascience) with $30 \mathrm{kDa}$ molecular weight cutoff. For quantifying the amount of conjugated peptide, free sulfhydryl groups before and after coupling were determined by Ellman's test (Pierce).

ELISA. To determine binding of phage clones to L3 and L4 antibodies, L3 or L4 antibodies ( $10 \mu \mathrm{g} / \mathrm{ml}$ in PBS, $50 \mu \mathrm{l}$ per well) were applied to MaxiSorp Immuno Modules (Nunc) and incubated overnight at $4^{\circ} \mathrm{C}$. Wells were blocked with $100 \mu$ l of blocking solution per well (1\% BSA in PBS, pH 7.4) for $1 \mathrm{~h}$ at room temperature, and $5 \times 10^{9}$ purified phages in $50 \mu \mathrm{l}$ of blocking buffer were added to each well and incubated for $1 \mathrm{~h}$ at room temperature. Plates were washed 5 times with $100 \mu \mathrm{l}$ of PBST (0.03\% Tween 20 in PBS, pH 7.4) and incubated with $50 \mu$ l of horseradish peroxidase (HRP)-conjugated M13 antibodies in blocking solution. The plates were then washed 5 times with PBST, and finally $0.5 \%$ $o$-phenylenediamine dihydrochloride (OPD; Pierce) was added. The absorbance was determined at $490 \mathrm{~nm}$ in a microtiter plate reader ( $\mu$ Quant, BioTek).

To monitor the binding between catalase-coupled peptides and L3 or L4 antibodies, wells of 96-well microtiter plates were coated with serial dilutions of catalase-coupled peptides in CANDOR blocking solution (CANDOR Bioscience; $50 \mu \mathrm{l}$ per well) overnight at $4^{\circ} \mathrm{C}$ and then wells were blocked with $100 \mu \mathrm{l}$ of CANDOR blocking solution for $1 \mathrm{~h}$ at room temperature. L3 and L4 antibodies $(10 \mu \mathrm{g} / \mathrm{ml} ; 50 \mu \mathrm{l}$ per well) in LowCross-Buffer (CANDOR Bioscience) were added to the wells and incubated for $1 \mathrm{~h}$ at room temperature. For competition ELISA, wells were coated with $40 \mu \mathrm{g} / \mathrm{ml}$ catalase-coupled peptides in blocking solution (50 $\mu \mathrm{l}$ per well), and L3 and L4 antibodies preincubated in $50 \mu \mathrm{l}$ of LowCross-Buffer with different concentrations of RNase B or EndoHtreated RNase B for 30 min were added to the wells and incubated for $1.5 \mathrm{~h}$ at room temperature. After washing with PBST for 5 times, $50 \mu \mathrm{l}$ of HRP-conjugated anti-rat secondary antibodies in LowCross-Buffer were added and incubated for $1 \mathrm{~h}$ at room temperature. The wells were then washed for 5 times with PBST, $0.5 \%$ OPD was added, and absorbance at $490 \mathrm{~nm}$ was determined.

To identify the oligomannose-specific interaction between AMOG and synapsin, $10 \mathrm{pmol}$ (in $50 \mu \mathrm{l}$ of PBS) of untreated or EndoH-treated AMOG was coated overnight at $4^{\circ} \mathrm{C}$. After washing with PBS and blocking with blocking solution (1\% BSA in PBS) for $1 \mathrm{~h}, 6.7 \mathrm{pmol}$ (in $50 \mu \mathrm{l}$ of blocking solution) of synapsin alone or preincubated for $30 \mathrm{~min}$ with 50 $\mu \mathrm{g} / \mathrm{ml}$ (in $50 \mu \mathrm{l}$ of blocking solution) oligomannoses isolated from AMOG upon EndoH-treatment was incubated for $1 \mathrm{~h}$ at room temperature. After washing, synapsin antibody was added, followed by the corresponding secondary antibody after washing with PBST. Wells were washed with PBST, OPD was added, and absorbance at $490 \mathrm{~nm}$ was determined. Alternatively, wells were coated with synapsin $(6.7 \mathrm{pmol} /$ well) overnight at $4^{\circ} \mathrm{C}$ and blocked for $1 \mathrm{~h}$ at room temperature, and increasing amounts of AMOG or EndoH-treated AMOG in 2\% BSA were added and incubated overnight at $4^{\circ} \mathrm{C}$. After washing with PBST, AMOG 
antibody in 2\% BSA was applied for $1 \mathrm{~h}$ at room temperature, and after washing with PBST, HRP-coupled secondary antibody in 2\% BSA was applied for $1 \mathrm{~h}$ at room temperature. After washing with PBST, 1\% OPD was used for detection at $490 \mathrm{~nm}$.

To investigate the interaction between synapsin and NCAM, $6.7 \mathrm{pmol}$ (in $50 \mu \mathrm{l}$ of PBS) of either untreated or EndoH-treated purified bovine synapsin was coated overnight at $4^{\circ} \mathrm{C}$. After blocking with $100 \mu \mathrm{l}$ of blocking solution (1\% BSA in PBS) at room temperature, $6.5 \mathrm{pmol}$ (in $50 \mu \mathrm{l}$ of blocking solution) of NCAM-Fc or CHL1-Fc preincubated with either untreated or EndoH-treated AMOG (40 pmol) at room temperature for 30 min was incubated at $4^{\circ} \mathrm{C}$ overnight. Plates were washed with TBST $(0.03 \%$ Tween 20 in PBS) and incubated with HRP-conjugated anti-human Fc antibody at room temperature for $1 \mathrm{~h}$. Wells were washed with TBST, OPD was added, and absorbance at $490 \mathrm{~nm}$ was determined.

Neurite outgrowth assay. Dissociated hippocampal neurons obtained from neonatal C57BL/6 wild-type and NCAM-deficient mice were used in neurite outgrowth experiments. Briefly, isolated hippocampi from mouse brains were placed in ice-cold dissection solution $(4.16 \mathrm{~mm}$ $\mathrm{NaHCO}_{3}, 10 \mathrm{~mm}$ HEPES, $34 \mathrm{~mm}$ D-glucose, $12 \mathrm{~mm} \mathrm{MgSO}$, $2.88 \mathrm{mg} / \mathrm{ml}$ $\mathrm{BSA}$, and $5 \mu \mathrm{g} / \mathrm{ml}$ gentamicin in HBSS) and then incubated in digestion solution $(5 \mathrm{mg} / \mathrm{ml}$ trypsin, $1 \mathrm{mg} / \mathrm{ml}$ DNase I, $135 \mathrm{~mm} \mathrm{NaCl}, 5 \mathrm{~mm} \mathrm{KCl}, 7$ $\mathrm{mm} \mathrm{Na}_{2} \mathrm{HPO}_{4}, 4.16 \mathrm{~mm} \mathrm{NaHCO}_{3}$, and $25 \mathrm{~mm}$ HEPES, pH 7.3) for $15 \mathrm{~min}$ at room temperature. The tissue was washed three times with ice-cold dissection solution and incubated in dissociation solution containing 1 $\mathrm{mg} / \mathrm{ml}$ DNase I using fire-polished Pasteur pipettes. Dissociated cells were resuspended in $10 \mathrm{ml}$ of dissection solution, centrifuged at $800 \times g$ for $10 \mathrm{~min}$ at $4^{\circ} \mathrm{C}$, and resuspended in culture medium (Neurobasal A supplied with $2 \mathrm{~mm}$ L-glutamine, $2 \%$ B27, and $5 \mu \mathrm{g} / \mathrm{ml}$ gentamicin). Cells at a density of $2.5 \times 10^{4}$ were seeded on coverslips coated with $0.01 \%$ poly-L-lysine (PLL), PLL with catalase or catalase-conjugated peptides $(100 \mu \mathrm{g} / \mathrm{ml})$, PLL with untreated, heat-denatured RNase B $\left(60^{\circ} \mathrm{C}\right.$ for 10 $\min )$ or EndoH-treated RNase B $(50 \mu \mathrm{g} / \mathrm{ml})$, native synapsin, heatdenatured synapsin, or EndoH-treated synapsin $(10 \mu \mathrm{g} / \mathrm{ml})$. For substrate coating, molecules were diluted in HBSS and incubated on coverslips overnight at $4^{\circ} \mathrm{C}$. Before seeding, coverslips were washed three times with ice-cold HBSS. After seeding, cells were cultured in the absence or presence of soluble synapsin $(10 \mu \mathrm{g} / \mathrm{ml})$ for $24 \mathrm{~h}$ in a humidified chamber at $37^{\circ} \mathrm{C}$ with $5 \% \mathrm{CO}_{2}$. In some experiments, RNase B diluted in prewarmed culture medium was added to the culture $1 \mathrm{~h}$ after seeding. Cultures were fixed with $2.5 \%$ glutaraldehyde and stained with $1 \%$ toluidine blue in $1 \%$ borax. The length of neurites was determined from neurons that were not in contact with other cells and had at least one process that was as long as the diameter of the cell body. Measurements were performed with AxioVision 4.6 software (Zeiss Microimaging).

Cell adhesion assay. Astrocytes were obtained from the cerebral cortex of newborn C57BL/6 mice (Won and Oh, 2000) and seeded as single-cell suspensions $\left(5 \times 10^{5}\right.$ cells $\left./ \mathrm{ml}\right)$ in DMEM with $10 \%$ fetal calf serum (FCS), $2 \mathrm{~mm}$ L-glutamine, and $50 \mathrm{U} / \mathrm{ml}$ penicillin/streptomycin onto tissue culture Petri dishes. On the third day of culture, the culture medium was replaced with serum-free medium. After $7 \mathrm{~d}$, freshly dissociated neurons obtained from the cerebellum of 7-d-old mice expressing green fluorescent protein as described previously (Husmann et al., 1992) were suspended in HBSS, adjusted to a cell density of $2 \times 10^{5}$ cells $/ \mathrm{ml}$, and seeded onto the monolayer of cultured astrocytes. Both astrocytes and neurons were independently preincubated with catalase or catalasecoupled peptides in $\mathrm{Ca}^{2+} / \mathrm{Mg}^{2+}$-free HBSS (CMF-HBSS) for 5 min on ice. Cocultures were incubated for $10 \mathrm{~min}$ at room temperature in a reciprocal shaker at $40 \mathrm{cycles} / \mathrm{min}$. Nonbound neurons were removed from the astrocyte monolayer by four gentle washings with CMF-HBSS. Adhering neurons were counted in at least 50 microscopic fields at 100fold magnification with an inverted fluorescence microscope (Zeiss Microimaging). Aggregated clusters of green cells were not counted.

Cross-linking assay. Sulfo-succinimidyl-2-[6-(biotinamido)-2-( $p$-azidobenzamido) hexanoamido] ethyl-1,3'-dithiopropionate (Sulfo-SBED, 0.25 $\mathrm{mg}$; Pierce Biotechnology) predissolved in $6 \mu$ l of DMSO was incubated with $200 \mu \mathrm{g}$ of catalase-coupled peptides resuspended in $200 \mu \mathrm{l}$ of PBS for $30 \mathrm{~min}$ in the dark under constant stirring at room temperature. Nonreacted crosslinker was removed by using Vivaspin concentrators with $10 \mathrm{kDa}$ molecular weight cutoff. Brains from 2-week-old wild-type mice were homogenized in ice-cold homogenization buffer [50 mm Tris-HCl, pH 7.5, 2 mM EDTA, and EDTA-free protease inhibitor cocktail (Roche Diagnostics)]. Homogenates were centrifuged at $1000 \times g$ for $10 \mathrm{~min}$ at $4^{\circ} \mathrm{C}$. $N$-Octyl $\beta$-D-glucopyranoside $(50 \mathrm{~mm})$ was added to the supernatant, and this crude homogenate was incubated overnight at $4^{\circ} \mathrm{C}$. The protein concentration was adjusted to 1 $\mathrm{mg} / \mathrm{ml}$ with homogenization buffer and the crosslinker conjugates were added and incubated with $1 \mathrm{ml}$ of the crude detergent-solubilized homogenate overnight at $4^{\circ} \mathrm{C}$ in the dark. The samples were then exposed to UV light $(365 \mathrm{~nm})$ for $15 \mathrm{~min}$ on ice to photoactivate the aryl azide group of the crosslinker and to covalently attach bound proteins. To enrich biotincarrying proteins, $50 \mu \mathrm{l}$ magnetic MagnaBind Streptavidin beads (Pierce Biotechnology) were incubated with the samples for $1 \mathrm{~h}$ at room temperature with mild rotation. Beads were washed 5 times with 2\% 3-[(3cholamidopropyl)dimethylammonio]-1-propanesulfonate (CHAPS, Sigma-Aldrich) in PBS. Beads were then boiled in sample buffer $(60 \mathrm{~mm}$ Tris/HCl, pH 6.8, 2\% SDS, $1 \% \beta$-mercaptoethanol, $10 \%$ glycerol, and $0.02 \%$ bromophenol blue) and resolved by SDS-PAGE under reducing conditions, resulting in a transfer of the biotin residue from the crosslinker to the bound protein(s). Biotinylated proteins were detected by Western blot analysis using HRP-conjugated streptavidin.

Immunoaffinity chromatography. Freeze-dried powder of $\mathrm{CNBr}-$ activated Sepharose 4B (120 mg; GE Healthcare) was incubated with $5 \mathrm{ml}$ of swelling solution $(1 \mathrm{~mm} \mathrm{HCl})$ for $15 \mathrm{~min}$ at $4^{\circ} \mathrm{C}$. The resin was washed three times with swelling solution and twice with $5 \mathrm{ml}$ of coupling solution $\left(100 \mathrm{~mm} \mathrm{NaHCO}_{3}, 500 \mathrm{~mm} \mathrm{NaCl}, \mathrm{pH} 8.3\right)$ for $15 \mathrm{~min}$ at $4^{\circ} \mathrm{C}$ and then pelleted by centrifugation at $200 \times g$ for $5 \mathrm{~min}$. Either L 3 or L4 antibodies $(200 \mathrm{mg})$ were incubated with pretreated resin in coupling solution overnight at $4^{\circ} \mathrm{C}$ with end-over-end rotation. The resin was washed with 10 $\mathrm{ml}$ of coupling buffer and remaining active groups were blocked by incubation with $5 \mathrm{ml}$ of blocking solution (200 mM glycine, $500 \mathrm{~mm} \mathrm{NaCl}$, $\mathrm{pH} 8.0)$ at $4^{\circ} \mathrm{C}$ with end-over-end rotation. After three cycles of washing with buffer A ( $100 \mathrm{~mm}$ sodium acetate and $500 \mathrm{~mm} \mathrm{NaCl}, \mathrm{pH} 4.0)$, buffer $\mathrm{B}\left(100 \mathrm{~mm} \mathrm{NaHCO}_{3}\right.$ and $500 \mathrm{~mm} \mathrm{NaCl}, \mathrm{pH}$ 8.3), and buffer C (PBS, pH 7.4), the resin was packed into a column. The column was washed with 20 $\mathrm{ml}$ of buffer D (25 mm Tris, $150 \mathrm{~mm} \mathrm{NaCl}$, and 5 mm EDTA, pH 7.4), and the brain extract was applied to the column overnight at $4^{\circ} \mathrm{C}$. The column was then washed with $10 \mathrm{ml}$ of buffer E ( $25 \mathrm{~mm}$ Tris, $150 \mathrm{~mm} \mathrm{NaCl}, 1 \%$ Triton X-100, and $0.02 \% \mathrm{NaN}_{3}, \mathrm{pH} 7.4$ ) followed by $10 \mathrm{ml}$ of buffer $\mathrm{F}$ ( 25 $\mathrm{mm}$ Tris/ $\mathrm{HCl}, 500 \mathrm{~mm} \mathrm{NaCl}, 0.1 \%$ Triton $\mathrm{X}-100$, and $0.02 \% \mathrm{NaN}_{3}, \mathrm{pH}$ 7.4). Proteins that bound to either L3 or L4 antibodies were eluted with elution buffer ( $50 \mathrm{~mm}$ ethanolamine, $150 \mathrm{~mm} \mathrm{NaCl}$, and 0.2\% CHAPS, $\mathrm{pH}$ 11.5). The eluates were dialyzed against TBS and concentrated with Vivaspin concentrators with $5 \mathrm{kDa}$ molecular weight cutoff.

Mass spectrometry. After SDS-PAGE, the gel was stained with colloidal Coomassie Blue (Roth) and protein bands were cut out. After successive treatment with dithiothreitol and iodoacetamide, in-gel digestion of proteins by $5 \mathrm{ng} / \mu$ l trypsin (Promega) in $50 \mathrm{mM} \mathrm{NH}_{4} \mathrm{HCO}_{3}$ was performed overnight at $37^{\circ} \mathrm{C}$. Gel pieces were then repeatedly extracted with $50 \%$ acetonitrile $/ 5 \%$ formic acid $/ 45 \%$ distilled water, and the combined extracts were dried down in a vacuum concentrator, redissolved in $5 \%$ methanol/5\% formic acid in water, desalted on a C18 $\mu$ ZipTip (Millipore), eluted with $1 \mu \mathrm{l}$ of $60 \%$ methanol/5\% formic acid/35\% water, and analyzed by nano-electrospray mass spectrometry in a QTOF II instrument (Micromass). The MS/MS spectra obtained by collision-induced fragmentation of the peptides were evaluated both manually and by the Mascot MS/MS ion search algorithm (Matrix Sciences).

Deglycosylation. For the EndoH-treatment, $10 \mu \mathrm{g}$ of glycoprotein, 10 $\mu \mathrm{l}$ of $5 \times$ reaction buffer ( $250 \mathrm{~mm}$ sodium acetate, $\mathrm{pH} 5.5$ ), and $2.5 \mu \mathrm{l}$ of $20 \times$ denaturing buffer ( $2 \%$ SDS and $10 \% \beta$-mercaptoethanol) were incubated in a total reaction volume of $45 \mu \mathrm{l}$ at $100^{\circ} \mathrm{C}$ for $10 \mathrm{~min}$. EndoH $\left(25 \mathrm{mU}\right.$ in $5 \mu \mathrm{l}$ ) was added and incubated at $37^{\circ} \mathrm{C}$ for $3 \mathrm{~h}$. For treatment with PNGase F, $10 \mu \mathrm{g}$ of glycoprotein, $10 \mu \mathrm{l}$ of $5 \times$ reaction buffer $(0.5 \mathrm{M}$ sodium phosphate, $\mathrm{pH} 7.4$ ), and $5 \mu$ l of $10 \times$ denaturing buffer (2\% SDS and $10 \% \beta$-mercaptoethanol) were incubated in a total reaction volume of $45 \mu \mathrm{l}$ at $100^{\circ} \mathrm{C}$ for $10 \mathrm{~min}$. Triton X-100 (2.5 $\left.\mu \mathrm{l} ; 10 \%\right)$ and PNGase F $(2.5 \mu \mathrm{l} ; 2.5 \mathrm{U})$ were added and incubated at $37^{\circ} \mathrm{C}$ for $3 \mathrm{~h}$.

Western blot analysis and lectin staining. Western blot analysis was performed as described previously (Kleene et al., 2007). For lectin staining, synapsin $(0.5 \mu \mathrm{g})$ was subjected to SDS-PAGE and transferred onto 
nitrocellulose membranes. Glycans on synapsin were detected by DIG glycan differentiation kit (Roche Diagnostics) according to the manufacturer's protocol.

Isolation and treatment of exosomes from astrocytes. Astrocyte-enriched cultures obtained from cortex or whole brain of 1- to 2-d-old mice were prepared as described previously (Won and Oh, 2000; Kleene et al., 2007) and cultured for 2 weeks or 1 week with serum-containing DMEM medium and then in serum-free DMEM medium for $12 \mathrm{~h}$, respectively. For hydrogen peroxide treatment, astrocytes were cultured for $6 \mathrm{~d}$ in serumcontaining DMEM medium and then in serum-free DMEM medium for $24 \mathrm{~h}$ in the absence or presence of $20 \mu \mathrm{m}$ hydrogen peroxide. For oxygen/ glucose deprivation, astrocytes obtained from whole brain were grown for $6 \mathrm{~d}$ in DMEM containing high glucose $(4.5 \mathrm{~g} / \mathrm{L})$ and supplemented with $10 \%$ FCS. The medium was replaced by serum-free DMEM containing low glucose $(1 \mathrm{~g} / \mathrm{L})$. For oxygen deprivation, cultures were placed into a humidified hypoxia chamber (Billups-Rothenberg) and flushed with $95 \% \mathrm{~N}_{2} / 5 \% \mathrm{CO}_{2}$ for $10 \mathrm{~min}$, and the sealed hypoxia chamber was incubated overnight at $37^{\circ} \mathrm{C}$.

All following steps were performed at $4^{\circ} \mathrm{C}$, unless stated otherwise. Cell culture supernatants were collected and centrifuged at $1000 \times g$ for 10 min. The resulting $1000 \times g$ supernatants were further centrifuged at $10,000 \times g$ for $30 \mathrm{~min}$ followed by centrifugation of the resulting supernatants at $100,000 \times g$ for $3 \mathrm{~h}$. The resulting pellets were either taken as exosome-enriched fraction for further analysis or were subjected to further enrichment by sucrose gradient centrifugation. Therefore, the $100,000 \times g$ pellet was resuspended in $2.5 \mathrm{M}$ sucrose buffered with $20 \mathrm{~mm}$ HEPES, pH 7.4, and overlaid with a sucrose step gradient $(2.25,2.0,1.75$, $1.5,1.25,1.0,0.75,0.5,0.25 \mathrm{M})$. The sucrose gradient was then centrifuged at $100,000 \times g$ for $5 \mathrm{~h}$ and 10 fractions were collected from the top of the gradient and diluted with $20 \mathrm{~mm}$ HEPES, $\mathrm{pH} 7.4$, and centrifuged at $100,000 \times g$ for $1.5 \mathrm{~h}$. Pellets from fractions enriched in synapsin and the exosomal marker proteins Alix and flotillin were combined and used for further analyses as indicated. For treatments of isolated exosomes, the pellet derived from the combined sucrose gradient fractions was resuspended in PBS and treated with for $5 \mathrm{~min}$ at $37^{\circ} \mathrm{C}$ under conditions as indicated. The samples were then centrifuged at $100,000 \times g$ for $1 \mathrm{~h}$. Cell culture supernatants were subjected to protein precipitation using $20 \%$ trichloroacetic acid. Proteins were collected by centrifugation at $20,000 \times g$ for $30 \mathrm{~min}$, and the resulting pellets were washed with acetone and resuspended in sample buffer. For preparation of cell lysates, astrocytes were collected in PBS using a cell scraper.

Electron microscopy. Pellets containing exosomes were incubated in fixing solution ( $4 \%$ paraformaldehyde and $1 \%$ glutaraldehyde in $0.1 \mathrm{~m}$ sodium phosphate buffer, $\mathrm{pH}$ 7.3) for $60 \mathrm{~min}$ at room temperature. After washing with PBS, pH 7.3, for 10 min, exosomes were embedded in $2 \%$ low-melting agarose, and postfixed with $1 \% \mathrm{OsO}_{4}$ in $0.1 \mathrm{M}$ sodium phosphate buffer, $\mathrm{pH}$ 7.3 , for $30 \mathrm{~min}$ on ice. Dehydration was performed by exposure to increasing concentrations of ethanol $(30 \%, 50 \%, 70 \%, 80 \%, 90 \%)$ followed by two incubation steps with $100 \%$ ethanol for $15 \mathrm{~min}$ and a final incubation with propylenoxid for $15 \mathrm{~min}$. Specimens were incubated with propylenoxid/ epoxy resin (1:1) for $90 \mathrm{~min}$ and with propylenoxid/epoxy resin (1:2) for $2 \mathrm{~h}$ followed by embedding in neat epoxy resin. Ultrathin sections were cut and analyzed with a Zeiss 902 electron microscope.

Cell surface biotinylation. Astrocyte-enriched cell cultures maintained for 7-9 d were washed twice with ice-cooled $\mathrm{PBS}^{2+}$ (PBS with $0.5 \mathrm{~mm}$ $\mathrm{CaCl}_{2}$ and $2 \mathrm{~mm} \mathrm{MgCl}_{2}$ ) and incubated for $10 \mathrm{~min}$ on ice with sulfoNHS-LC-biotin (Thermo Scientific) freshly prepared in ice-cooled $\mathrm{PBS}^{2+}$. After treating the cells with $20 \mathrm{~mm}$ glycine in $\mathrm{PBS}^{2+}$ for 5 min on ice, cells were washed twice with ice-cooled $\mathrm{PBS}^{2+}$ and lysed with RIPA buffer [50 mm Tris/HCl, pH 7.4, $150 \mathrm{~mm} \mathrm{NaCl}, 1 \% \mathrm{NP} 40$, and protease inhibitor cocktail (Roche)] for $30 \mathrm{~min}$ at $4^{\circ} \mathrm{C}$ with mild shaking. Lysed cells were collected using a rubber scraper, centrifuged for $10 \mathrm{~min}$ at $1000 \times g$ and $4^{\circ} \mathrm{C}$. Streptavidin-coupled magnetic beads (Pierce Biotechnology) were added to the lysate and incubated overnight at $4^{\circ} \mathrm{C}$. After washing the beads twice with RIPA buffer and once with $\mathrm{PBS}^{2+}$, beads were boiled in sample buffer and the eluate resulting from centrifugation at $10,000 \times g$ for 5 min was saved for further analyses.

Immunoprecipitation and double immunostaining. For immunoprecipitation of synapsin, cell lysates or cell culture supernatants were incu- bated overnight with synapsin antibody at $4^{\circ} \mathrm{C}$ under constant rotation. Then, protein A/G agarose beads (Santa Cruz Biotechnology) were added and the incubation was continued for $3 \mathrm{~h}$ at $4^{\circ} \mathrm{C}$. After sedimentation, beads were then washed twice with RIPA buffer and once with PBS and boiled in SDS sample buffer. The eluate from the beads was subjected to Western blot analysis.

For double immunostaining, astrocyte-enriched glial cell cultures were prepared from whole mouse brain and maintained for $6 \mathrm{~d}$ on PLL. All following steps were performed at room temperature. After removing the culture medium, cells were fixed by incubation with $4 \%$ formaldehyde for $10 \mathrm{~min}$, washed twice with PBS, incubated for $1 \mathrm{~h}$ with $0.1 \%$ BSA $/ 0.3 \%$ Triton X-100 followed by incubation with primary antibodies resuspended in PBS containing $0.1 \%$ BSA. After three washes with PBS, the corresponding secondary antibodies labeled with the fluorescent dye Cy 2 or Cy3 were resuspended in PBS with $0.1 \%$ BSA and incubated for $1 \mathrm{~h}$ with fixed cells. After two washes with PBS, coverslips were mounted with Roti-Mount FluorCare DAPI (Roth). Immunopositive cells in five view fields were counted under the inverted fluorescence microscope at $20 \times$ magnification. The numbers relative to the number of DAPIstained nuclei were calculated from two independent experiments.

Neuronal cell death assay. Dissociated cortical neurons were obtained from E16-E17 mouse embryos. Briefly, pregnant mice were killed with $\mathrm{CO}_{2}$ inhalation, uterus and embryos were exposed, and cerebral cortices were removed, dissected, and incubated in digestion solution ( $0.025 \%$ trypsin in HBSS) for $15 \mathrm{~min}$ at $37^{\circ} \mathrm{C}$. After addition of $1 \%$ BSA and $1 \%$ trypsin inhibitor in HBSS, the samples was centrifuged at $800 \times g$ for $10 \mathrm{~min}$ and the pellet was resuspended in culture medium (Neurobasal A supplied with $2 \mathrm{~mm}$ L-glutamine, $2 \% \mathrm{~B} 27$, and $5 \mu \mathrm{g} / \mathrm{ml}$ gentamicin) and triturated with a firepolished Pasteur pipette. Dissociated cells were seeded onto PLL- and synapsin $\left(1.5 \mu \mathrm{g} /\right.$ well)-coated 48 -well plates at a density of $2 \times 10^{5}$ cells in 250 $\mu \mathrm{l}$ of medium per well. After $24 \mathrm{~h}$ in a humidified chamber at $37^{\circ} \mathrm{C}$ with $5 \%$ $\mathrm{CO}_{2}, 20 \mu \mathrm{m}$ hydrogen peroxide was added to the cells, which were incubated under these conditions for $24 \mathrm{~h}$. Cells were stained with calcein $(1 \mu \mathrm{g} / \mathrm{ml})$ and propidium iodide $(2 \mu \mathrm{g} / \mathrm{ml})$ for $30 \mathrm{~min}$ at $37^{\circ} \mathrm{C}$ in a humidified chamber and then washed with culture medium. Live cells stained with calcein and dead cells stained with propidium iodide in each corresponding view field were quantified under the inverted fluorescence microscope at $20 \times$ magnification. At least four view fields were quantified for each well using the AxioVision 4.6 software (Zeiss Microimaging). Cell survival was determined as live cell/total cell ratio, and survival in the nonstressed control group was set as $100 \%$.

Oxygen/glucose deprivation. Dissociated cortical neurons were obtained from E16 mouse embryos and seeded onto PLL- or synapsin-coated plastic plates at a density of with $5 \times 10^{5}$ cells/ml in Neurobasal A medium supplemented with B-27, 2 mm L-glutamine, and antibiotics. After $2 \mathrm{~d}$, the conditioned cell culture medium was removed and saved. Cells were washed twice with prewarmed deoxygenated PBS (gassed for 30 min with $\mathrm{N}_{2}$ ) and incubated in deoxygenated PBS without or with $20 \mu \mathrm{g} / \mathrm{ml}$ synapsin. Cultures were then placed into a humidified hypoxia chamber (Billups-Rothenberg) and flushed with $100 \% \mathrm{~N}_{2}$ for $10 \mathrm{~min}$. The sealed hypoxia chamber with the treated cell cultures was placed into an incubator at $37^{\circ} \mathrm{C}$ for $3 \mathrm{~h}$. Reoxygenation was induced by removing PBS and adding the previous conditioned cell culture media and further maintained for $12 \mathrm{~h}$ in an incubator at $37^{\circ} \mathrm{C}$. Cell survival was estimated as described above.

Coculture experiments. Primary glial cultures were prepared from P0 wild-type or synapsin I/II/III triple knock-out (TKO) (Gitler et al., 2004) C57B/L6 mice (with modifications from Kaech and Banker, 2006). Briefly, cortices were dissected in ice-cold HBSS and incubated in $0.25 \%$ trypsin plus $1 \mathrm{mg} / \mathrm{ml}$ DNase for $30 \mathrm{~min}$ at $37^{\circ} \mathrm{C}$. Cells were centrifuged, resuspended in glial culture medium (MEM, 10\% horse serum, $33 \mathrm{~mm}$ glucose, and antibiotics) and plated onto PLL-coated $25 \mathrm{~mm}$ glass coverslips at low density (45,000 cells per coverslip). After $24 \mathrm{~h}$, the medium was replaced with fresh glial culture medium, and cells were grown to confluence for 2 weeks. Hippocampal neurons obtained from E18 C57BL/6 wild-type embryos [with modifications from Kaech and Banker (2006)] were plated on mature glial cultures that had been starved for $48 \mathrm{~h}$ in neuronal medium (Neurobasal with B27 supplement, $2 \mathrm{~mm}$ glutamine, and antibiotics). Cocultures were grown for $24 \mathrm{~h}$, fixed, and stained with antibody against neurofilament heavy chain (SMI-31) and 

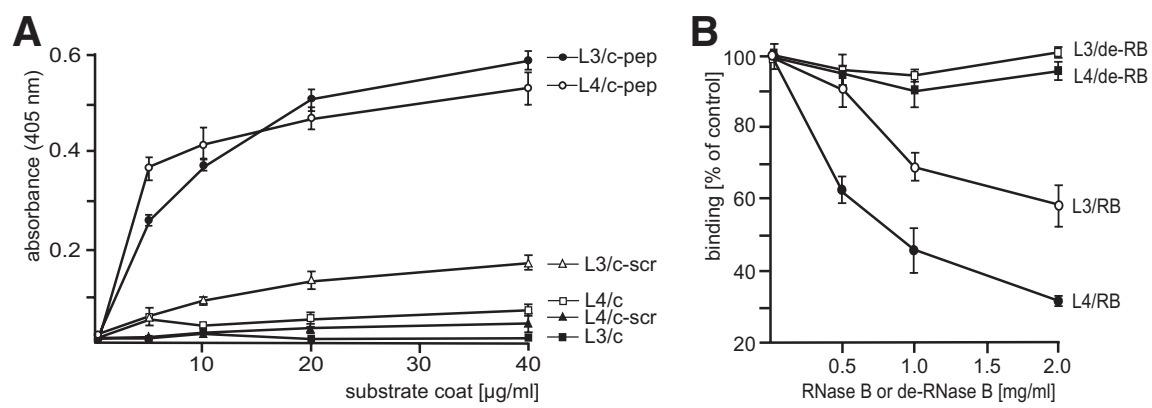

Figure 1. Characterization of a synthetic oligomannose-mimicking peptide. $\boldsymbol{A}$, Binding of $L 3$ and $L 4$ antibodies to increasing amounts of substrate-coated catalase (c), catalase-coupled putative oligomannose-mimicking peptide (c-pep), or catalasecoupled scrambled peptide ( $(-s c r)$ was determined by ELISA. B, L3 and L4 antibodies were preincubated with various amounts of untreated RNase B (RB) or EndoH-treated, deglycosylated RNase B (de-RB) and added to the substrate-coated putative oligomannose-mimicking peptide. Binding of the antibodies was determined by ELISA. Mean values \pm SEM from at least three independent experiments are shown.

against $\beta$-III tubulin antibody (T2200) to identify axons and the neurite network, respectively. Images were acquired with an Olympus BX51 upright microscope equipped with a Neurolucida XY stage and motorized $\mathrm{Z}$ movement, using a UPlanFL N $20 \times / 0.50$ objective, and the filter cubes Semrock CY5-4040A and Olympus FITC U-MNIBA3. Images were visualized with the Neurolucida Version 8 software (MBF-Bioscience). Sholl analysis was performed using the Sholl plugin of the ImageJ software. Axonal length and branching were measured using the NeuronJ plugin of the ImageJ software. Mean area staining intensity was determined by using the ImageJ software.

\section{Results}

Identification of an oligomannose-mimicking peptide

The aim of our project was to identify novel oligomannoserecognizing receptors in mouse brain. Because oligomannosidic glycans from natural sources are only available in limited amounts and also difficult to synthesize chemically, we had to use a surrogate to achieve our goal. Peptides have shown to structurally and functionally mimic oligosaccharides (Pirofski, 2001; Johnson et al., 2002; Monzavi-Karbassi et al., 2002) and thus are potential surrogates for carbohydrates. Therefore, we first attempted to isolate an oligomannose-mimicking peptide. The oligomannoserecognizing antibodies L3 and L4 (Fahrig et al., 1990) were used in a phage display screen to isolate oligomannose-mimicking peptides from a 12-mer peptide library. Phages that bound to L3 and L4 antibodies were eluted with antibody and/or sugar and further analyzed by ELISA using L3 or L4 antibodies as substrate coat. One phage obtained by antibody and sugar elution showed very strong binding to both antibodies (data not shown) and expressed the peptide sequence TISWWHLWPSPA. A synthetic peptide with this sequence was used for further analyses to verify that this peptide is indeed an oligomannose-specific glycomimetic. The synthetic peptide, which showed low solubility in aqueous buffers, was conjugated to the soluble carrier protein catalase to improve solubility and to increase the binding avidity of the peptide to its binding partners. First, the binding of the oligomannose-specific antibodies L3 and L4 to substrate-coated peptide coupled to catalase was analyzed. Both antibodies showed a concentration-dependent and saturable binding to the catalase-coupled peptide, whereas they showed only a very weak binding to catalase or to catalase-coupled control peptide with a scrambled sequence of the mimicking peptide (Fig. $1 \mathrm{~A}$ ).

To confirm that the peptide is an oligomannose-mimicking peptide, we tested whether the binding of the oligomannose-specific antibodies to the peptide was oligomannose dependent. Therefore, we performed a competition ELISA using oligomannose-bearing RNase B for competition and EndoH-treated oligomannose-lacking
RNase B as control. In the presence of untreated RNase B, the binding of the antibodies to the substrate-coated catalase-coupled peptide decreased in a concentrationdependent manner, while EndoH-treated RNase B, being devoid of oligomannoses, showed no effect on the binding (Fig. $1 B$ ). This result confirms that the peptide indeed is an oligomannose-mimicking peptide, because it competes with the oligomannoses on RNase B for binding to the antibodies L3 and L4.

\section{The oligomannose-mimicking peptide stimulates neurite outgrowth and disturbs adhesion between neurons and astrocytes}

Next, we performed functional tests to investigate whether the oligomannosemimicking peptide is functionally active. Since oligomannoses have been reported to promote neurite outgrowth (Chandrasekaran et al., 1991; Tanzer et al., 1993), we tested whether also the oligomannose-mimicking peptide had this effect. Hippocampal neurons were seeded onto substrate-coated catalase-coupled oligomannose-mimicking peptide. Oligomannose-carrying RNase B served as positive control and PLL, catalase, catalase-coupled scrambled peptide, and EndoH-treated oligomannose-lacking RNase B were used as negative controls. In comparison to PLL, neurite outgrowth of hippocampal neurons was promoted on substratecoated catalase-coupled oligomannose-mimicking peptide and on oligomannose-carrying RNase B, while substrate-coated catalase, catalase-coupled scrambled peptide and oligomannose-lacking EndoH-treated RNase B were virtually ineffective (Fig. 2A).

Since oligomannose-binding antibodies L3 and L4 have been shown to interfere with the adhesion between neurons and astrocytes (Fahrig et al., 1990), we also investigated whether the oligomannose-mimicking peptide affected the interaction between neurons and astrocytes. In a short-term adhesion assay, cerebellar neurons were plated onto cultured cortical astrocytes in the presence of catalase or catalase coupled to either oligomannose-mimicking peptide or scrambled peptide. In the presence of catalase-coupled oligomannose-mimicking peptide, adhesion between neurons and astrocytes decreased by $50 \%$ with respect to the control, while adhesion in the presence of catalase or scrambled peptide-coupled catalase was not or only slightly affected, respectively (Fig. $2 \mathrm{~B}$ ). These results confirm that the oligomannose-mimicking peptide is functionally active in stimulating neurite outgrowth and inhibiting adhesion of neurons to astrocytes.

\section{Identification of synapsin as oligomannose-binding lectin}

Next, we used the oligomannose-mimicking peptide in crosslinking experiments with the aim to identify novel oligomannosebinding proteins in mouse brain. Oligomannose-mimicking peptide and scrambled peptide coupled to catalase, and catalase alone, were conjugated to the trifunctional crosslinker sulfoSBED, and these conjugates were used as baits to isolate bound target proteins from crude brain homogenate. By UV crosslinking, target proteins were covalently attached to the bait proteins and isolated via the biotin moiety present on the crosslinker. Reducing conditions during gel electrophoresis led to transfer of the biotin label from the bait to the bound target protein(s). Western blot analysis with streptavidin to detect biotinylated 

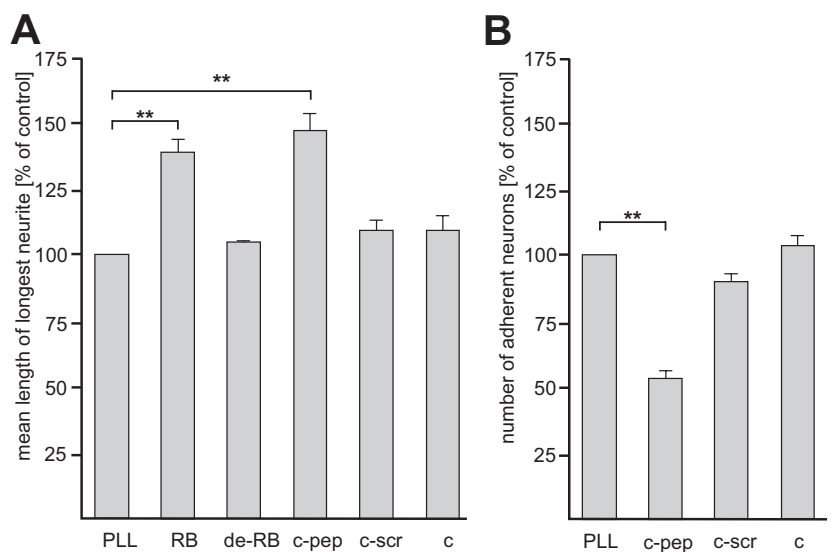

Figure 2. The oligomannose-mimicking peptide promotes neurite outgrowth and disturbs adhesion of neurons to cortical astrocytes. $\boldsymbol{A}$, Hippocampal neurons were grown on substratecoated PLL alone or with catalase (c), catalase-coupled oligomannose-mimicking peptide (cpep), catalase-coupled scrambled peptide (c-scr), RNase B (RB), or deglycosylated RNase B (de-RB). After $24 \mathrm{~h}$ in culture, cells were fixed and the length of the longest neurite per cell was determined. Mean length of the longest neurites obtained from PLL treatment was set to $100 \%$. $\boldsymbol{B}$, Freshly prepared GFP-expressing cerebellar granule neurons were preincubated with either solvent alone (control), catalase (c), catalase-coupled oligomannose-mimicking peptide (cpep), or catalase-coupled scrambled peptide (c-scr) and subsequently added to a monolayer of cultured cortical astrocytes pretreated with solvent alone, catalase (c), catalase-coupled oligomannose-mimicking peptide (c-pep), or catalase-coupled scrambled peptide (c-scr). After removal of nonadherent cells, GFP-positive cells attached to the astrocyte monolayer were quantified. The mean number of adherent cells in the solvent-treated (PLL) control was set to $100 \%$. Mean values \pm SEM of three independent experiments are shown $\left({ }^{* *} p<0.01\right.$; oneway ANOVA followed by Dunnett's multiple-comparison test).

proteins revealed a very intense staining of a protein band with an apparent molecular weight of $75 \mathrm{kDa}$ and a weak staining of several other protein bands, when catalase-coupled oligomannosemimicking peptide was used as bait, whereas no biotinylated protein was detectable when catalase or catalase-coupled scrambled peptide was used as bait (Fig. 3A). Protein bands showing an apparent molecular weight of $\sim 75 \mathrm{kDa}$ were cut out from a Coomassie Bluestained gel (Fig. 3B), and mass spectrometry of these bands identified synapsin I (Table 1) (hereafter called synapsin). To confirm that synapsin was identical to the $75 \mathrm{kDa}$ protein that predominantly bound to the oligomannose-mimicking peptide, Western blot analysis using synapsin-specific antibodies was carried out. A strong synapsin signal around $75 \mathrm{kDa}$ was observed when the oligomannose-mimicking peptide was used as bait, whereas no signal or a very weak signal was seen when either catalase or catalasecoupled scrambled peptide was used as bait, respectively (Fig. 3C).

To further confirm that synapsin acts as an oligomannosespecific lectin, the binding of purified synapsin or synapsin preincubated with AMOG-derived oligomannoses to substratecoated oligomannose-bearing AMOG or to EndoH-treated, oligomannose-free AMOG was determined in ELISA experiments. Synapsin showed binding to untreated oligomannosecarrying AMOG, but a reduced binding to EndoH-treated oligomannose-lacking AMOG (Fig. 3D). The binding of synapsin to AMOG was also reduced when synapsin was preincubated with AMOG-derived oligomannose (Fig. 3D). An ELISA experiment performed by applying increasing amounts of AMOG or EndoH-treated AMOG to substrate-coated synapsin showed a concentration-dependent saturable binding of untreated oligomannose-carrying AMOG, but no binding of EndoH-treated oligomannose-lacking AMOG to synapsin (Fig. 3E). These results indicate that synapsin is indeed an oligomannose-binding lectin-like protein.

\section{Synapsin is a glycoprotein}

In an attempt to identify novel oligomannose-carrying proteins, immunoaffinity chromatography with L3, L4, or nonimmune control antibody using mouse brain extracts was performed. Western blot analysis using L3 or L4 antibody revealed a very prominent L3- and L4-positive band of $\sim 75 \mathrm{kDa}$ in the eluates from the L3 and L4 antibody columns, but not in the eluate from the control antibody column (Fig. 4A,B). This result suggested that the $75 \mathrm{kDa}$ protein is the most prominent oligomannose carrier. According to the molecular weight, we considered the possibility that the $75 \mathrm{kDa}$ protein was synapsin and probed the eluates with synapsin antibodies in Western blot analysis. A strong signal at $75 \mathrm{kDa}$ was observed in the eluates from to L3 and L4 columns, but no visible band was observed in the eluate from the control antibody column (Fig. 4C). These results imply that synapsin is a major oligomannose carrier. To further confirm that synapsin is a glycoprotein, purified synapsin was digested with EndoH to remove oligomannose, or with PNGase F to remove all $N$-glycans. Western blot analysis showed that synapsin deglycosylated by EndoH or PNGase F was no longer recognized by L3 and L4 antibodies, but it was still detected by the synapsin antibody (Fig. 4D). These results show that synapsin carries $\mathrm{N}$-glycans and, thus, is a glycoprotein. Since synapsin has been reported to carry fucose in $\alpha 1,2$-linkage to galactose (Murrey et al., 2006) and we showed that it carries oligomannose, we further characterized the glycosylation of purified synapsin using carbohydrate-specific antibodies and lectins. No synapsin staining was observed with antibodies recognizing the HNK-1 epitope or polysialic acid, while L5 antibody, which recognizes Lewis ${ }^{\mathrm{x}}$, bound to synapsin (Fig. $4 E$ ). The persistence of synapsin staining by the L5 antibody after treatment with PNGase F (data not shown) indicates that Lewis ${ }^{\mathrm{x}}$ is present on O-linked glycans of synapsin. All tested lectins showed binding to synapsin (Fig. 4F). These results indicate that synapsin is a glycoprotein carrying $\mathrm{N}$-glycans and $\mathrm{O}$-glycans.

\section{Synapsin is present in exosomes isolated from astrocyte- enriched cell cultures}

Since synapsin was found to be both a glycoprotein and a glycanbinding protein, it was conceivable that it is released from the cell and functions as an extracellular protein. So far, synapsin is known to be a neuron-specific protein associated with the cytoplasmic side of synaptic vesicles and regulating synaptic vesicle trafficking. However, it has been reported that synapsin is also expressed by other cell types, including cultured astrocytes, albeit at much lower levels (Maienschein et al., 1999). Therefore, we first used cultured neurons and astrocytes for immunocytochemistry and cell surface biotinylation to check whether synapsin was detectable as an extracellular protein at the cell surface of these cells. Synapsin immunoreactivity was not detectable at the cell surface by immunostaining of live neurons of different origin, such as hippocampal, cerebellar, and cortical neurons, as well as astrocytes isolated from cortex or whole brain of neonatal mice (data not shown). Since cultured cortical astrocytes have been shown to express synapsin (Maienschein et al., 1999), we used this cell culture system for the following analyses. For comparison and because of higher yields, astrocyte-enriched cultures from whole brain, which we had used previously (Kleene et al., 2007), were used in most of the following experiments either in parallel to or instead of cortical astrocyte-enriched cultures. After cell surface biotinylation, isolation of biotinylated protein by streptavidin beads, and Western blot analysis of biotinylated proteins, synapsin immunoreactivity was detected in the samples 
A

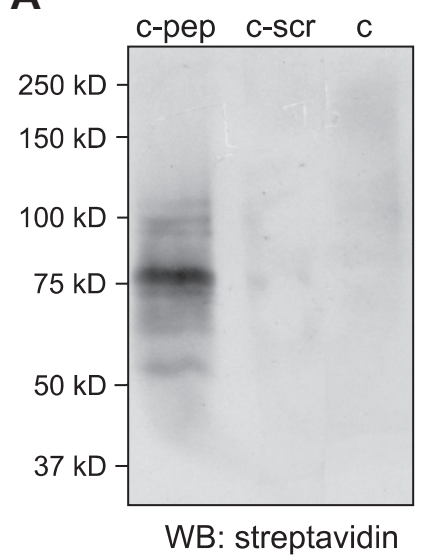

D

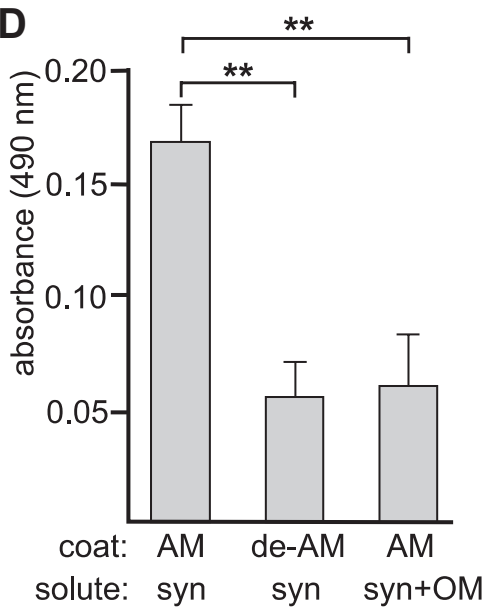

B

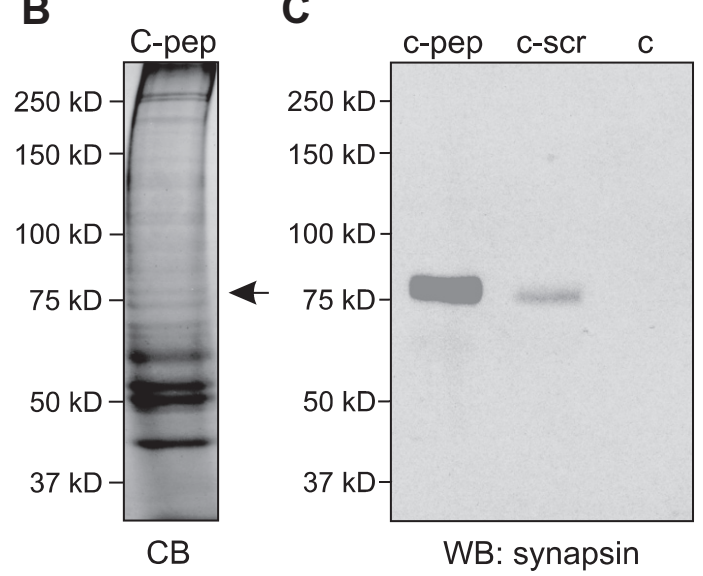

E

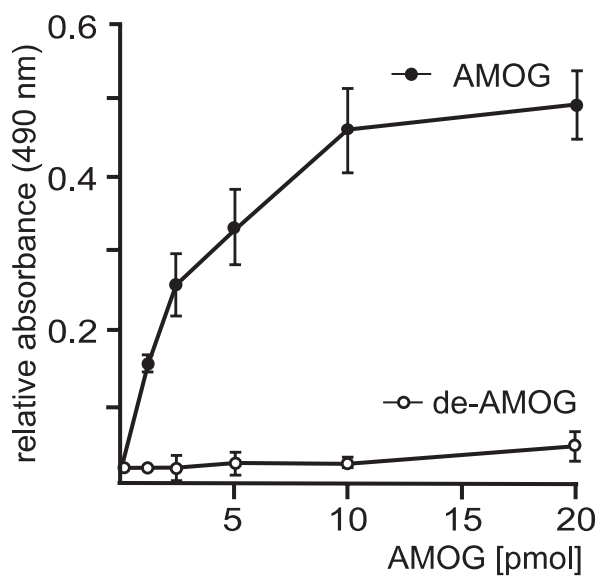

Figure 3. Synapsin is an oligomannose-specific lectin. Either catalase (c), catalase-coupled oligomannose-mimicking peptide (c-pep), or catalase-coupled scrambled peptide (c-scr) was conjugated to the biotin-carrying multifunctional and cleavable crosslinker sulfo-SBED. The conjugates were incubated with detergent extracts of crude brain homogenate. After UV crosslinking, proteins bound to the conjugates were isolated, separated by gel electrophoresis and subjected to Western blot analysis using HRP-coupled streptavidin $(\boldsymbol{A})$, Coomassie Blue staining (CB) with the arrow indicating the position of the protein band identified as synapsin $(\boldsymbol{B})$, or Western blot analysis with synapsin antibody $(\boldsymbol{C})$. D, Synapsin preincubated in the absence (syn) or presence (syn + OM) of AMOG-derived oligomannose was incubated with substrate-coated untreated AMOG (AM) or EndoH-treated, deglycosylated AMOG (de-AM). The binding of synapsin was determined by ELISA using a synapsin antibody and background staining was subtracted. Mean values \pm SEM of three independent experiments are indicated ( ${ }^{* *} p<0.01$; one-way ANOVA followed by Dunnett's multiple-comparison test). $\boldsymbol{E}$, Increasing amounts of AMOG (AM) or EndoH-treated, deglycosylated AMOG (de-AM) were incubated with substrate-coated synapsin. The binding of AMOG was determined by ELISA using an AMOG antibody and background staining was subtracted. Mean values \pm SEM of three independent experiments are indicated.

Table 1. Mass spectrometry of the $75 \mathrm{kDa}$ protein band isolated by crosslinking with immobilized oligomannose-mimicking peptide revealed six peptide masses that match to mouse synapsin

\begin{tabular}{|c|c|c|c|c|c|c|}
\hline $\begin{array}{l}\mathrm{m} / \mathrm{z} \\
\text { submitted }\end{array}$ & $\mathrm{MH}^{+}$matched & $\Delta \mathrm{Da}$ & Start & End & $\begin{array}{l}\text { Missing } \\
\text { cleavages }\end{array}$ & Peptide sequences \\
\hline 1187.69 & 1186.68 & -0.019 & 177 & 186 & 0 & RSLKPDFVLIRQ \\
\hline 1635.78 & 1635.87 & -0.090 & 115 & 128 & 0 & VLLVIDEPHTDWAK ${ }^{a}$ \\
\hline 1756.82 & 1756.78 (MSO) & 0.040 & 337 & 352 & 0 & TNTGSAMLEQIAMSDR $^{a}$ \\
\hline 1804.86 & $1804.76(\mathrm{Pho})$ & 0.100 & 337 & 352 & 0 & TNTGSAMLEQIAMSDR $^{a}$ \\
\hline 2051.99 & 2050.98 & 0.017 & 86 & 108 & 0 & QTTAAAAATFSEQVGGGSGGAGR ${ }^{a}$ \\
\hline 2378.23 & 2377.19 & -0.003 & 508 & 531 & 0 & RLPSPTAAPQQSASQAT $^{a}$ \\
\hline
\end{tabular}

${ }^{a}$ Sequence was confirmed by postsource decay fragment ion mass analysis.

obtained from astrocyte-enriched cultures derived from cortex and whole brain (Fig. $5 A$ ), but not in the sample derived from cerebellar neurons (data not shown). As seen before by Western blot analysis (Kleene et al., 2007), astrocytic marker proteins, such as GFAP or AMOG, but not neuronspecific markers, such as $\beta$-III tubulin or L1, were detected in our glial cell cultures (data not shown), indicating that our cell culture system is enriched in astrocytes. Densitometric analysis of the signal intensities obtained for synapsin in the eluate and for total synapsin indicated that $\sim 10 \pm 5 \%$ of total synapsin was present in the eluate containing biotinylated proteins, suggesting that this amount of synapsin expressed by cultured astrocytes is exposed at the cell surface. As a control, Western blot analysis using a GAPDH antibody revealed that GAPDH was not present in the eluate containing biotinylated proteins (Fig. 5A). To confirm that synapsin was indeed biotinylated and did not merely coisolate with biotinylated transmembrane cell surface proteins, synapsin was immunoprecipitated after cell surface biotinylation of cultured cortical astrocytes and the immunoprecipitates were subjected to Western blot analysis using either HRP-conjugated streptavidin or the synapsin antibody. In comparison to a strong signal at $75 \mathrm{kDa}$ seen for synapsin with the synapsin antibody, low, but clearly detectable, amounts of only one $75 \mathrm{kDa}$ protein were observed with streptavidin labeling (Fig. $5 B$ ), indicating that a significant amount of immunoprecipitated synapsin was biotinylated and thus was exposed at the cell surface of astrocytes. No bands were observed when a nonimmune control antibody was used for immunoprecipitation (Fig. 5B). An approximate estimation of the signal intensities obtained for immunoprecipitated, biotinylated synapsin and total synapsin by densitometry revealed that $5 \pm 4 \%$ of synapsin expressed by cultured cortical astrocytes is exposed at the cell surface.

In a next step, we tested the possibility that synapsin is released from cells via exosomes, which mediate the transport of cytosolic proteins from one cell to another cell or to the extracellular milieu [for review, see Simons and Raposo (2009)]. Exosomes are formed by invaginations at the membrane of multivesicular bodies and they pinch-off from these invaginations as intraluminal vesicles into the lumen of the multivesicular bodies, resulting in packaging of cytoplasmic proteins inside of these vesicles (for review, see Lakkaraju and Rodriguez-Boulan, 2008). The intraluminal vesicles are released as exosomes into the extracellular space upon fusion of multivesicular bodies with the plasma membrane. Via this pathway, the interior of exosomes contains cytoplasmic proteins, such as synapsin. Western blot analysis showed that synapsin was expressed in astrocyteenriched cell cultures and that a significant amount of exosomes that contain synapsin and the exosomal marker protein Alix could be isolated by serial centrifugation from the cell culture supernatant of cultures enriched in cortical astrocytes (Fig. 5C). In addition, other soluble, cytoplasmic proteins, such as hsc70, 


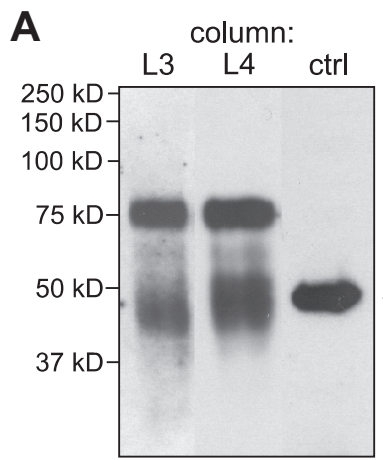

WB: L3
B column: C
C

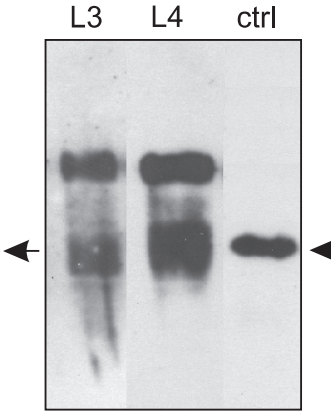

WB: L4

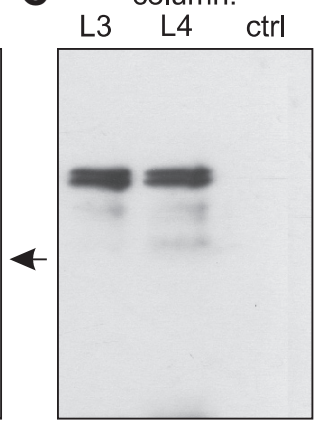

WB: synapsin
D

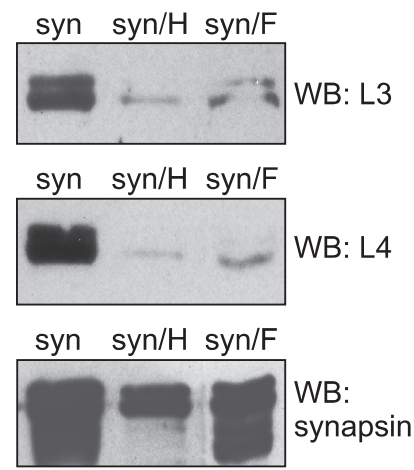

E

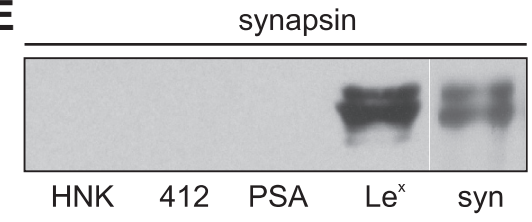

$\mathbf{F}$

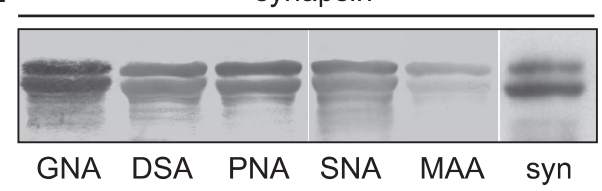

Figure 4. Synapsin is an oligomannose-bearing glycoprotein. Eluates from $L 3, L 4$, or control (ctrl) antibody columns were probed with oligomannose reactive $L 3(\boldsymbol{A})$ or $L 4(\boldsymbol{B})$ antibody or with synapsin antibody (C). The band around $50 \mathrm{kDa}$ (arrow) represents the heavy chain of antibodies leaking from the column. $\boldsymbol{D}$, Purified bovine synapsin was incubated in the absence (syn) or in the presence of EndoH (syn/H) or PNGase $F$ (syn/F) and subjected to Western blot analysis using L3, L4, or synapsin antibody. $E, F$, Purified bovine synapsin was either subjected to Western blot analysis with antibodies against synapsin (syn) $(\boldsymbol{E}, \boldsymbol{F})$, HNK1 (HNK, 412) $(\boldsymbol{E})$, polysialic acid (PSA) $(\boldsymbol{E})$, and Lewis ${ }^{\mathrm{x}}\left(\mathrm{Le}^{\mathrm{x}}\right)(\boldsymbol{E})$ or tested for lectin staining using Galanthus nivalis agglutinin $(\mathrm{GNA})$, Datura stramonium agglutinin (DSA), peanut agglutinin (PNA), Sambucus nigra agglutinin (SNA), and Maackia amurensis agglutinin (MAA) (F).

actin, and GAPDH, which all have been found in exosomes (Simpson et al., 2008), and proteins of the endoplasmic reticulum, such as PDI, were also detected in cell lysates and in exosomes from cultures enriched in cortical astrocytes (Fig. 5C). However, synaptophysin and 14-3-3 were detectable in the cell lysates, but not in exosomes derived from astrocyte-enriched cell cultures (Fig. 5C). Although cerebellar neurons expressed large amounts of synapsin, only negligible amounts of exosomes were obtained from cultured neurons, such as cerebellar or cortical neurons (data not shown). Therefore, we used cultured cortical astrocytes to enrich exosomes from cell culture supernatants by serial centrifugation and sucrose gradient centrifugation. Analysis of the gradient fractions showed that synapsin was detectable in exosomal fractions enriched in the exosomal marker proteins Alix and flotillin (Fig. 5D). The analysis of the combined exosomal fractions by electron microscopy showed a high degree of homogeneity: 95\% of the particles were vesicles with a diameter of $\sim 80 \mathrm{~nm}$ (Fig. $5 E$ ), which fits well with the reported size of exosomes (Simons and Raposo, 2009). These results imply that synapsin is released from cortical astrocytes via exosomes.

To investigate whether soluble synapsin is also present in the extracellular medium, cell-free cell culture supernatants from astrocyte-enriched cell cultures were used for immunoprecipitation either before or after removal of exosomes by ultracentrifugation. Western blot analysis of the immunoprecipitates with synapsin antibody showed that a proportion of synapsin could be immunoprecipitated from the cell culture supernatant both before and after removal of exosomes (Fig. $5 F$ ). However, the amount of immunoprecipitated synapsin was reduced by $\sim 70 \%$ when exosomes had been removed from the cell culture supernatant, indicating that synapsin was predominantly released from astrocytes via exosomes.

\section{Synapsin is released from glial-derived exosomes and is} neuroprotective under conditions of oxidative stress and ischemia The presence of significant amounts of soluble synapsin in the cell culture supernatant of cultured glial cells raised the question of whether synapsin is directly released from glial cells as soluble protein or whether it is released from these cells as soluble protein via exosomes. To address the question whether synapsin is released from the lumen of exosomes under certain conditions, such as stress or high metabolic activity, we first exposed isolated exosomes under conditions that prevail at high neuronal activity, namely elevated $\mathrm{K}^{+}$concentrations. Therefore, exosomes from cell cultures enriched in cortical astrocytes were resuspended in PBS and incubated in the absence or presence of increasing $\mathrm{KCl}$ concentrations. After ultracentrifugation, the pelleted exosomes and the supernatant fractions containing proteins released from exosomes were subjected to Western blot analysis. After incubation in PBS or in the presence of increasing concentrations from 40 to $70 \mathrm{~mm} \mathrm{KCl}$, synapsin was exclusively found in the pellet fraction, but not in the supernatant (Fig. 5G), indicating that it was not released from exosomes, while PDI was completely released from the exosomes already by $55 \mathrm{~mm} \mathrm{KCl} \mathrm{(Fig.} \mathrm{5G).} \mathrm{In} \mathrm{the}$ presence of $75 \mathrm{~mm} \mathrm{KCl}$, small amounts of synapsin were observed in the supernatant (Fig. 5G), whereas in the presence of $80 \mathrm{~mm}$ $\mathrm{KCl}$, the vast majority of synapsin was present in the supernatant and only very small residual amounts were seen in the pellet fraction (Fig. $5 G$ ). Actin, which was also detectable in exosomes (Fig. 5C), or the soluble exosomal marker protein hsc70 (data not shown), was not released from the exosomes under these conditions (Fig. $5 G$ ). It is noteworthy that synapsin was also released from exosomes by addition of $80 \mathrm{~mm} \mathrm{LiCl}$, but not at lower concentrations, whereas addition of $80 \mathrm{~mm} \mathrm{NaCl}$ did not promote release of synapsin (data not shown). Synapsin was also not released at lower $\mathrm{pH}$ values, namely $\mathrm{pH}$ 6.0, or in the presence of $0.23 \mathrm{M}$ sucrose or $1.5 \mathrm{mM} \mathrm{MgCl}_{2} / 1.5 \mathrm{mM} \mathrm{CaCl}_{2}$ (data not shown). However, in the presence of $1.5 \mathrm{mM} \mathrm{MgCl}_{2} / 1.5 \mathrm{mM} \mathrm{CaCl}_{2}$, the release of synapsin by $80 \mathrm{~mm} \mathrm{KCl}$ was inhibited (Fig. $5 \mathrm{G}$ ). These results indicate that elevated concentrations of $\mathrm{KCl}$ or $\mathrm{LiCl}$, but not of $\mathrm{NaCl}$, result in a release of synapsin from isolated glialderived exosomes and that the release at elevated $\mathrm{KCl}$ concentrations is inhibited in the presence of physiological concentrations 

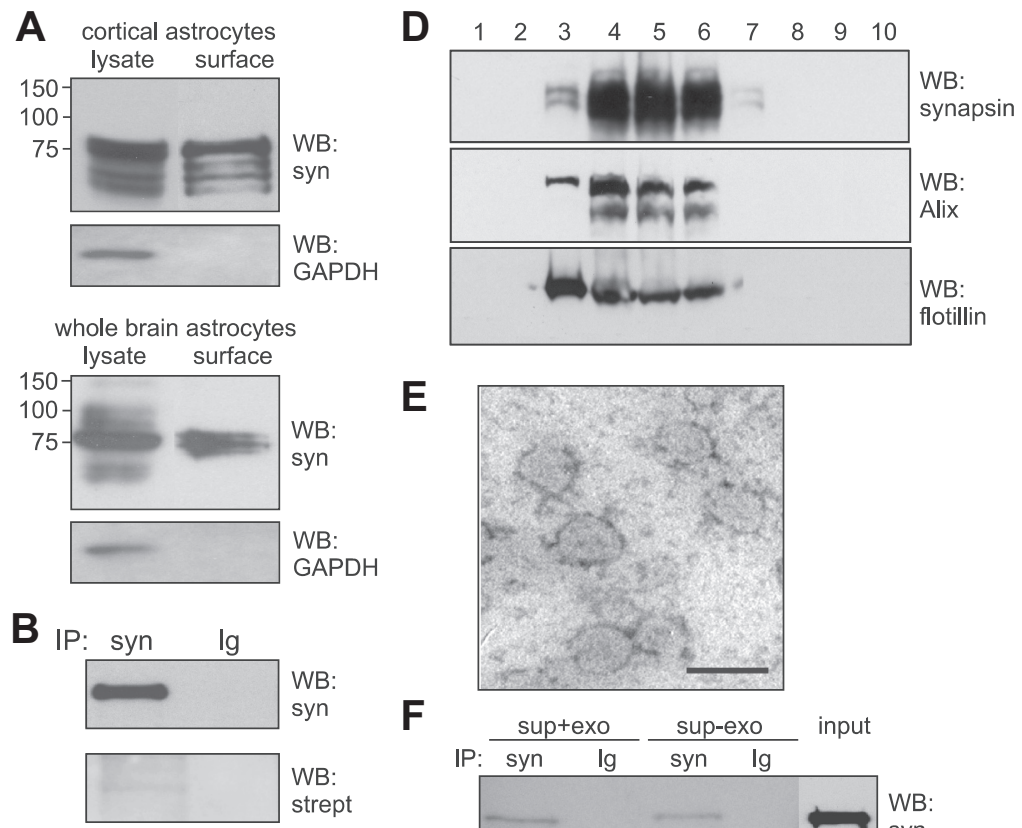

$E$

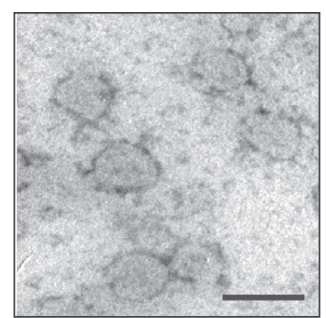

$\mathbf{F}$
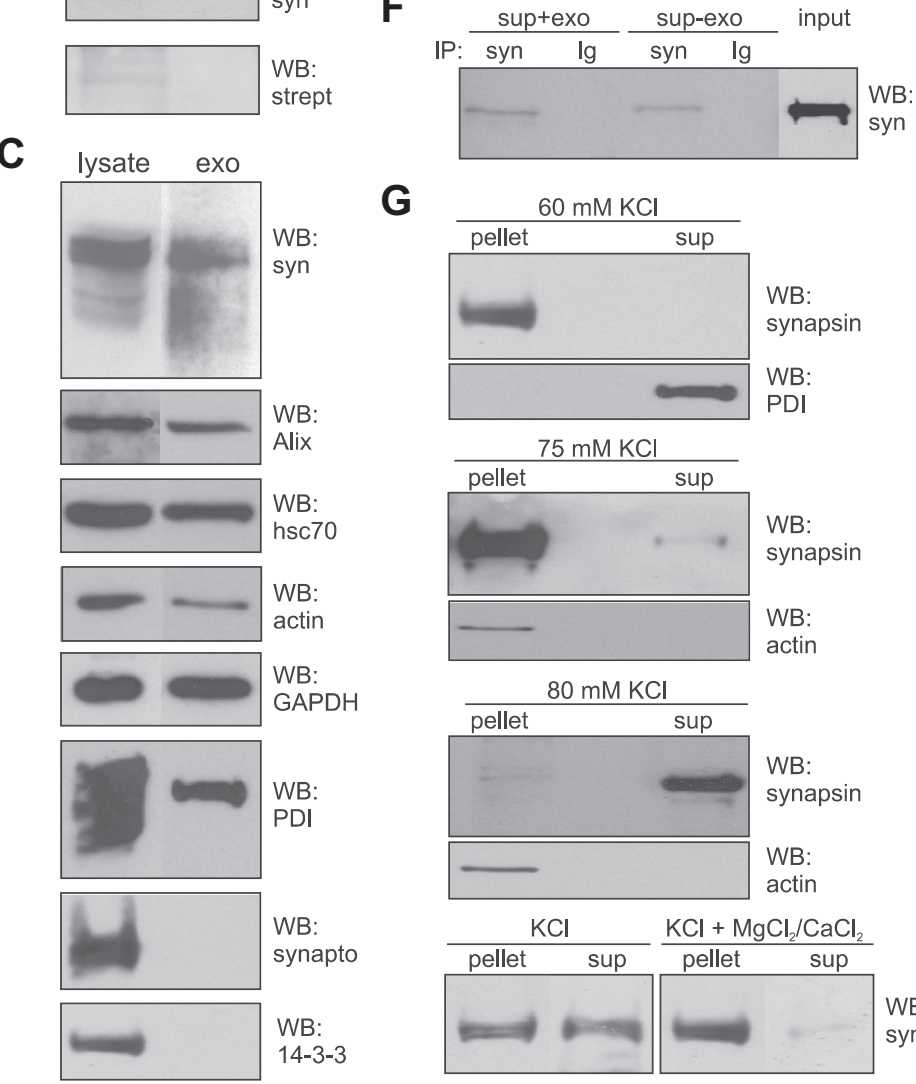

G
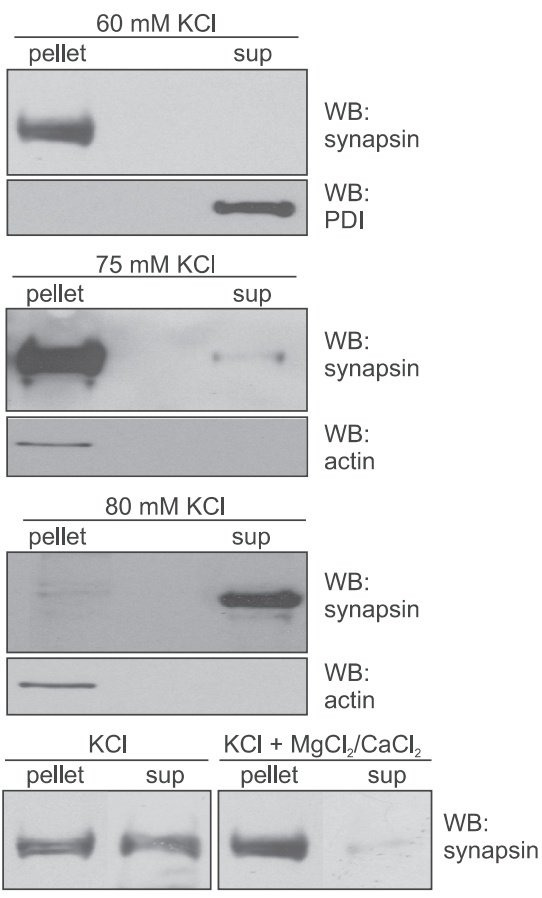

Figure 5. Synapsin is localized at the cell surface of cultured glial cells and present in glia-derived exosomes. $A$, Cultured cortical or whole-brain astrocytes were subjected to cell surface biotinylation and biotinylated cell surface proteins were isolated using streptavidin-conjugated beads. Lysates and biotinylated proteins (surface) were subjected to Western blot analysis (WB) with synapsin (syn) or GAPDH antibody. B, Biotinylated proteins were used for immunoprecipitation (IP) with synapsin antibody (syn) or nonimmune control antibody $(\mathrm{lg})$ and the resulting immunoprecipitates were subjected to Western blot analysis using HRPcoupled streptavidin (strept) or synapsin antibody (syn). C, Lysates and crude exosomal fractions (exo) isolated from the cell culture supernatant of cultured mouse cortical astrocytes by serial centrifugation were probed in Western blot analysis with synapsin, Alix, hsc70, actin, GAPDH, PDI, synaptophysin (synapto), or 14-3-3 antibodies. D, Crude exosomes were subjected to sucrose gradient centrifugation. After centrifugation fractions were collected and probed in Western blot analysis using synapsin, Alix, and flotillin antibodies. $\boldsymbol{E}$, Fractions of exosomes that contain synapsin were analyzed by electron microscopy (scale bar, $100 \mathrm{~nm}$ ). $\boldsymbol{F}$, Cell-free cell culture supernatant of cortical astrocytes (sup + exo) or the supernatant obtained after $100,000 \times g$ centrifugation of the cell culture supernatant of cortical astrocytes (sup-exo) were subjected to immunoprecipitation (IP) with synapsin antibody (syn) or nonimmune control antibody (lg). The immunoprecipitates were subjected to Western blot (WB) analysis using synapsin (syn) antibody. G, Exosomes isolated from astrocyte culture supernatant were incubated in the presence of 60,75 , or $80 \mathrm{~mm} \mathrm{KCl}$ without (KCl) or with $1.5 \mathrm{~mm} \mathrm{MgCl}$ and $\mathrm{CaCl}_{2}\left(\mathrm{KCl}+\mathrm{MgCl}_{2} / \mathrm{CaCl}_{2}\right)$. After incubation for $5 \mathrm{~min}$ at $37^{\circ} \mathrm{C}$, samples were centrifuged at $100,000 \times g$ to isolate exosomes (pellet) and proteins released from the exosomes (sup) by subjecting the supernatant to protein precipitation. The pellet and supernatant fractions were subjected to Western blot analysis using synapsin, actin, or PDI antibodies. of $\mathrm{Ca}^{2+}$ and $\mathrm{Mg}^{2+}$ ions, suggesting that the release of synapsin from exosomes is not due to an nonspecific effect of high ionic strength.

$\mathrm{KCl}$ concentrations up to $80 \mathrm{~mm}$ can be reached during propagation of spreading depression (SD) waves (for review, see Irwin and Walz, 1999) in the normal and the diseased or injured brain under pathological oxidative stress conditions, such as ischemia/stroke (for review, see Lauritzen et al., 2011). SD waves lead to an activation of microglia and astrocytes, which have neuroprotective functions (for review, see Irwin and Walz, 1999). These observations led to the idea that synapsin may be released from glial-derived exosomes under oxidative stress conditions to protect neurons against oxidative stress. To test this idea, we treated astrocyteenriched cell cultures isolated from cortex or from whole brain of neonatal mice with concentrations of hydrogen peroxide that cause oxidative stress and determined the amounts of synapsin levels in exosomes and in the cell culture supernatant after removal of exosomes. In the presence of hydrogen peroxide, the amount of exosome-associated synapsin decreased and the amount of soluble synapsin in the cell culture supernatant increased in comparison to that observed in the absence of hydrogen peroxide (Fig. 6A). The amounts of other exosome-associated and/or cytoplasmic proteins, such as Alix or GAPDH, in exosomes and cell culture supernatants as well as the expression of synapsin in astrocytes were not affected by hydrogen peroxide (Fig. 6A).

Similarly, determination of cell death showed that survival of cultured astrocytes was not significantly affected by hydrogen peroxide treatment: only $5.2 \pm$ $2.9 \%$ of all cells were found to be dead. Densitometric quantification indicates that hydrogen peroxide resulted in a $2.6 \pm$ 0.7 -fold increase of synapsin levels in the cell culture supernatant $(n=8 ; p<0.005)$ and a concomitant $6.5 \pm 0.2$-fold decrease of synapsin in exosomes $(n=6 ; p<$ 0.005 ). Interestingly, treatment of isolated exosomes with hydrogen peroxide did not lead to a significant release of synapsin. In summary, the results indicate that synap$\sin$ is released from glia-derived exosomes under oxidative stress conditions.

Subsequently, we addressed the question whether extracellular synapsin protects neurons from oxidative stress. Survival of cultured cortical neurons grown on substrate-coated synapsin or on control substrate PLL and in the absence or presence of hydrogen peroxide was determined. 
A
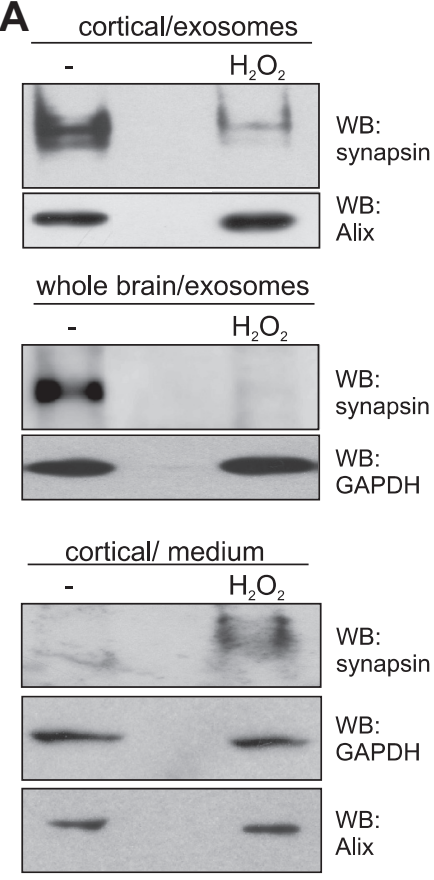

whole brain/ medium
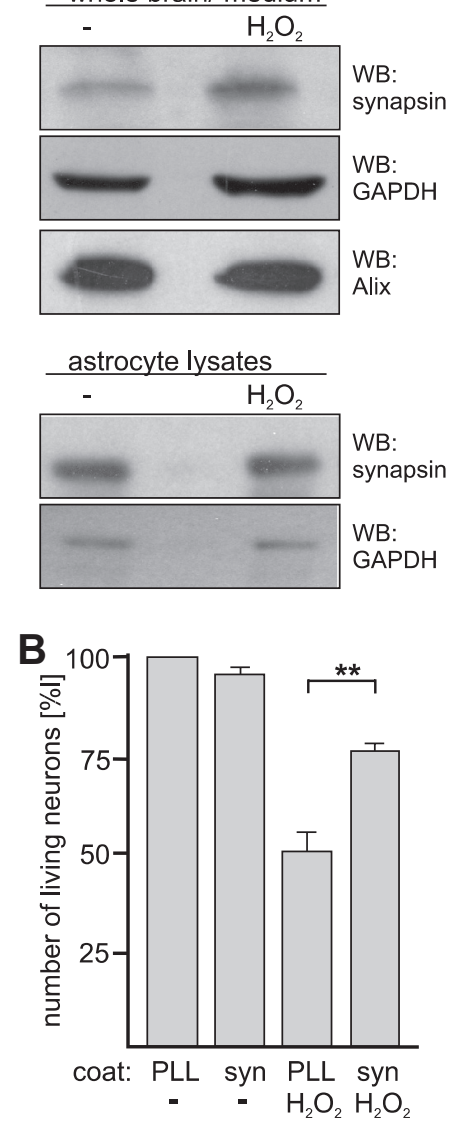

C
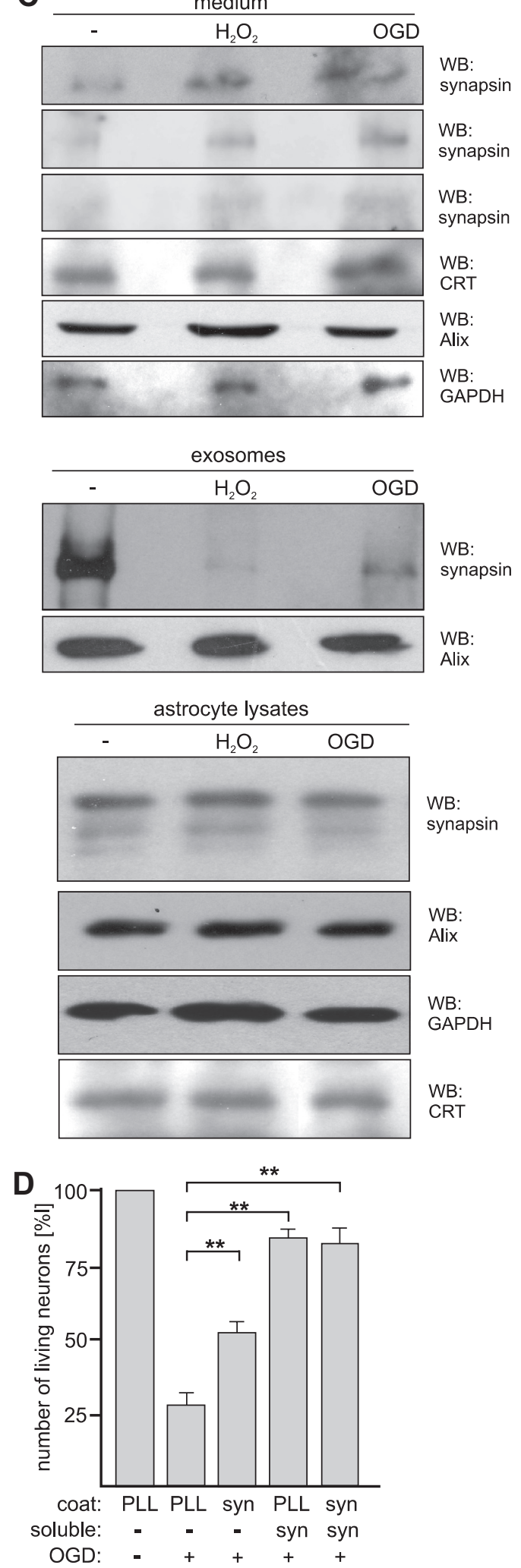

Figure 6. Synapsin released from exosomes of cultured glia cells is neuroprotective under oxidative stress conditions. $\boldsymbol{A}$, Cell culture supernatants from cortical and whole-brain glial cells cultured in the absence or presence of $20 \mu \mathrm{m}$ hydrogen peroxide $\left(\mathrm{H}_{2} \mathrm{O}_{2}\right)$ were subjected to serial centrifugation. After centrifugation at $100,000 \times g$, the resulting pellets containing exosomes and supernatants (medium) containing soluble proteins were subjected to Western blot analysis with synapsin and Alix or GAPDH antibodies. The cells were also lysed and probed with synapsin and GAPDH antibodies in Western blot analysis. $\boldsymbol{B}$, Cortical neurons were grown on substrate-coated PLL or synapsin in the absence or presence of $20 \mu \mathrm{m}$ hydrogen peroxide $\left(\mathrm{H}_{2} \mathrm{O}_{2}\right)$. After $24 \mathrm{~h}$, neurons were stained with calcein and propidium iodide to determine the number of live and dead cells. Cell survival (ratio

In the absence of hydrogen peroxide, survival of neurons on substrate-coated synapsin was similar to that on PLL. In the presence of hydrogen peroxide, neuronal cell death increased on both substrates, but survival of neurons was increased on the synapsin coat relative to that determined on the control substrate PLL (Fig. 6B). This result indicates that extracellular synapsin is able to protect neurons from oxidative stress.

We further examined the release of synapsin under oxidative stress conditions by subjecting astrocyte-enriched cell cultures from whole brain to ischemic conditions induced by oxygen/glucose deprivation or glucose deprivation in the presence of hydrogen peroxide. After 7-9 $\mathrm{d}$ in culture, cells were incubated in medium with low glucose in the absence or presence of hydrogen peroxide under normoxic or hypoxic conditions. In comparison to normoxic control conditions and in the absence of hydrogen peroxide, hydrogen peroxide treatment as well as hypoxia in combination with glucose deprivation led to a $2.6 \pm 0.4$-fold increase of synapsin in the cell culture supernatant $(n=4 ; p<0.05)$ and to a $6.7 \pm 0.4$-fold decrease of synapsin in exosomes $(n=4$; $p<0.05$ ), while the amount of synapsin in cell lysates was not altered (Fig. 6C). The amounts of GAPDH, Alix, and calreticulin in the cell culture supernatants and cell lysates as well as the amounts of Alix in exosomes were not altered by either treatment (Fig. 6C).

To investigate whether extracellular synapsin protects neurons from oxygen/

$\longleftarrow$

between number of live cells and total cell number) was calculated and survival of control cells was set to $100 \%$. C, Cell culture supernatants from whole-brain glial cells subjected to glucose deprivation and either hypoxia (OGD) or hydrogen peroxide $\left(\mathrm{H}_{2} \mathrm{O}_{2}\right)$ treatment were applied to serial centrifugation. After centrifugation at $100,000 \times g$, the resulting supernatants (medium) containing soluble proteins and pellets containing exosomes were subjected to Western blot analysis with synapsin, Alix, GAPDH, or calreticulin (CRT) antibodies. Cell lysates were probed with synapsin, Alix, calreticulin, and GAPDH antibodies. D, Cortical neurons grown on substratecoated PLL or synapsin were subjected to oxygen/glucose deprivation (OGD) in the absence or presence of soluble synapsin. After $3 \mathrm{~h}$, neurons were stained with calcein and propidium iodide to determine the number of live and dead cells. Cell survival was analyzed as described above (B). $\boldsymbol{A}, \boldsymbol{C}$, Representative blots out of at least two blots from at least three independent experiments are shown. C, Western blots of the cell culture supernatants probed with synapsin antibody from three independent experiments are shown. $\boldsymbol{B}, \boldsymbol{D}$, Mean values \pm SEM of three independent experiments are shown $\left({ }^{* *} p<0.01\right.$ obtained by one-way ANOVA with Turkey's multiple-comparison test). 
glucose deprivation, cultured cortical neurons grown on substrate-coated synapsin or on the control substrate PLL were subjected to oxygen/glucose deprivation in the absence or presence of soluble synapsin. In comparison to the control conditions without oxygen/glucose deprivation, a dramatic increase of neuronal death was observed upon oxygen/glucose deprivation. Neurons grown on substrate-coated synapsin and/or in the presence of soluble synapsin showed a higher survival rate upon oxygen/glucose deprivation than neurons grown on PLL and, thus, in the absence of synapsin (Fig. 6D). These results indicate that extracellular synapsin protects neurons from ischemia and cell death.

\section{Synapsin promotes neurite outgrowth in an oligomannose-dependent manner}

So far, synapsin has been considered as a protein extrinsically associated with the cytoplasmic surface of small synaptic vesicles. Here, we have demonstrated that cultured astrocytes release synapsin via synapsin-containing exosomes and that synapsin can be released from exosomes into the extracellular medium by elevated $\mathrm{KCl}$ concentrations or oxidative stress or ischemic conditions.

To investigate whether extracellular synapsin may affect neuronal development, we first analyzed whether neurite outgrowth is affected when neurons are exposed to exogenous substratecoated or soluble synapsin mimicking cell-associated or soluble extracellular synapsin, respectively. In comparison to neurons maintained on PLL, a pronounced increase in neurite lengths was observed both when hippocampal neurons were maintained on substrate-coated synapsin and when they were maintained in the presence of soluble synapsin (Fig. 7A). Neurite outgrowth in the concomitant presence of substrate-coated and soluble synapsin was not significantly changed relative to that observed in the presence of soluble synapsin or of substrate-coated synapsin alone (Fig. 7A). In summary, the results suggest that that extracellular synapsin released by astrocytes promotes neurite outgrowth. To evaluate the physiological role of glia-derived synapsin proteins in mediating neuronal growth, we plated wildtype hippocampal neurons on glial cultures derived from either wild-type or synapsin I/II/III TKO mice. We chose to use synapsin TKO animals rather than synapsin I knock-out to avoid the possibility that other members of the synapsin family might compensate for the lack of synapsin I in the system. Hippocampal neurons were maintained on glial cultures for $24 \mathrm{~h}$, fixed, and stained with antibodies against neurofilament heavy chain and $\beta$-III tubulin to identify axons and the neurite network, respectively (Fig. 7B). Sholl analysis performed on neuronal profiles showed that wild-type hippocampal neurons grown on synapsin TKO cells have a simpler neurite network than neurons grown in parallel on wild-type glia (Fig. 7C). Quantification of axonal growth and branching also revealed that wild-type neurons maintained on synapsin TKO glia display shorter and less branched axons than neurons maintained on wild-type glia (Fig. $7 D$ ). Altogether, these results support the idea that synapsin proteins secreted from glial cells contributes to the optimal growth of neurons.

We next analyzed whether extracellularly localized synapsin affects neuritogenesis as an oligomannose-carrying and -binding protein. Neurite outgrowth on substrate-coated native synapsin was very similar to that on denatured synapsin (data not shown), and it was higher than that on control substrate PLL, while neurite outgrowth on substrate-coated EndoH-treated denatured synapsin was similar to that on PLL (Fig. 7E). To further analyze whether the neurite-promoting effect of synapsin depends on oligomannose, oligomannose-bearing RNase B, EndoH-treated oligomannose-lacking RNase B, or oligomannose-mimicking peptide coupled to catalase was added to the medium to block the binding of synapsin to oligomannoses at the cell surface and/or to inhibit the recognition of oligomannoses on synapsin by cell surface receptors. In the presence of oligomannose-carrying untreated RNase B or catalase-coupled oligomannose-mimicking peptide, the synapsininduced promotion of neurite outgrowth was virtually abolished, while in the presence of EndoH-treated RNase B devoid of oligomannose, the synapsin-induced neurite outgrowth was not altered (Fig. 7E). These results indicate that the enhancement of neurite outgrowth by extracellular synapsin is oligomannose dependent.

\section{Synapsin binds to the extracellular domain of NCAM in an oligomannose-dependent manner and promotes neurite outgrowth in an NCAM-dependent manner}

Glia, such as astrocytes, is involved in functional modulation of neuronal properties, such as neurite outgrowth. Since synapsin is released from astrocytes via exosomes and promotes neurite outgrowth in an oligomannose-dependent manner, it is likely that the binding of the extracellular glial-derived oligomannose-bearing synapsin to neuronal oligomannose-binding cell surface receptors may trigger neurite outgrowth. NCAM is an oligomannose-binding neuronal protein involved in neurite outgrowth (Horstkorte et al., 1993; Heiland et al., 1998) and thus is a prime candidate to interact with synapsin in an oligomannose-dependent manner. First, we investigated by ELISA whether NCAM binds to synapsin using NCAM-Fc, and CHL1-Fc as negative control. The binding of NCAM-Fc to substrate-coated denatured synapsin, but not to EndoH-treated denatured synapsin, increased in a concentrationdependent and saturable manner, while CHL1-Fc did not show any binding to substrate-coated synapsin (Fig. $8 A$ ). In a similar ELISA experiment using increasing amounts of NCAM-Fc and a constant amount of denatured or EndoH-treated denatured synapsin as substrate coat, a concentration-dependent and saturable binding of NCAM-Fc to substrate-coated synapsin, but not to EndoH-treated synapsin, was observed (Fig. $8 B$ ). To confirm that NCAM binds to oligomannoses on synapsin, we performed a competition ELISA with NCAM-Fc using either untreated or EndoH-treated synapsin as substrate coat in the presence of untreated oligomannose-bearing AMOG or EndoH-treated AMOG as competitors. NCAM-Fc bound to synapsin, but not to deglycosylated synapsin (Fig. 8C). When NCAM-Fc was preincubated with oligomannose-bearing AMOG, binding of NCAM-Fc to synapsin decreased to levels obtained with deglycosylated synapsin (Fig. 8C). In contrast, preincubation with EndoH-treated oligomannose-lacking AMOG had no effect on binding of NCAM-Fc to synapsin (Fig. 8C). These results demonstrate an oligomannose-dependent binding of NCAM to synapsin.

Since synapsin promotes neurite outgrowth and interacts with NCAM in an oligomannose-dependent manner, it is reasonable to assume that the effects of synapsin on neurite outgrowth are mediated by its interaction with NCAM. Thus, we measured neurite outgrowth using NCAM-deficient hippocampal neurons and found that synapsin did not enhance neurite outgrowth in these neurons (Fig. 8D). This result indicates that promotion of neurite outgrowth by extracellular synapsin is mediated by its oligomannose-dependent interaction with NCAM at the cell surface of neurons.

\section{Synapsin is expressed by glial cells}

To verify the expression of synapsin in primary astrocytes, the astrocyte-enriched cell culture isolated from whole brain was 
A

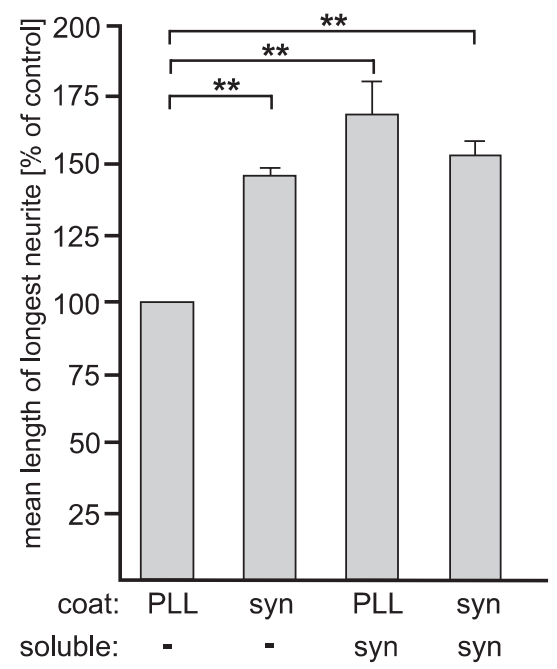

B

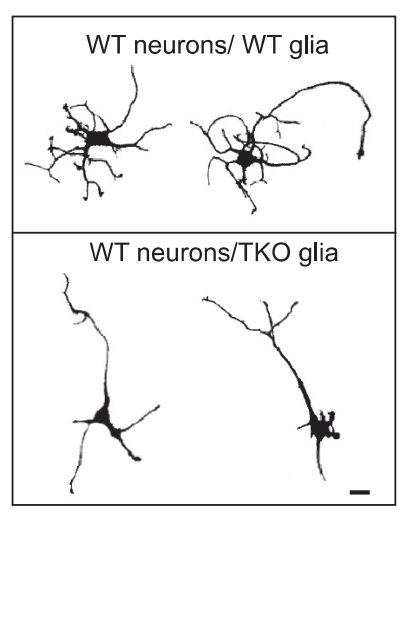

C

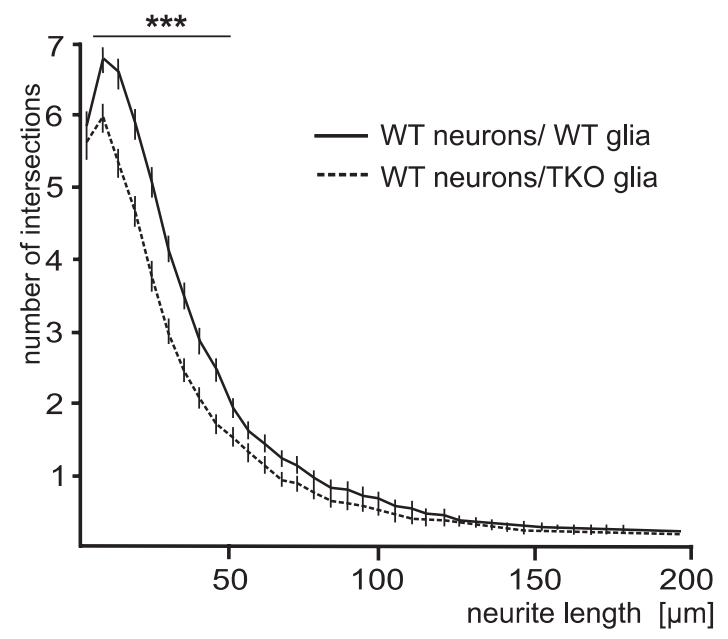

D

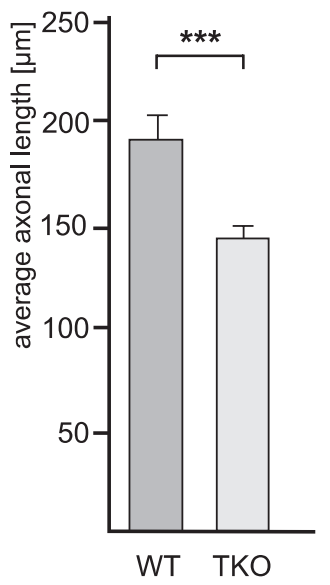

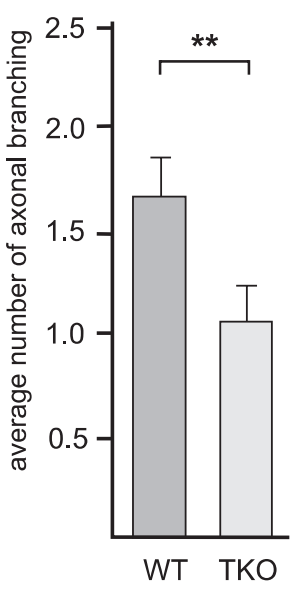

$\mathrm{E}$

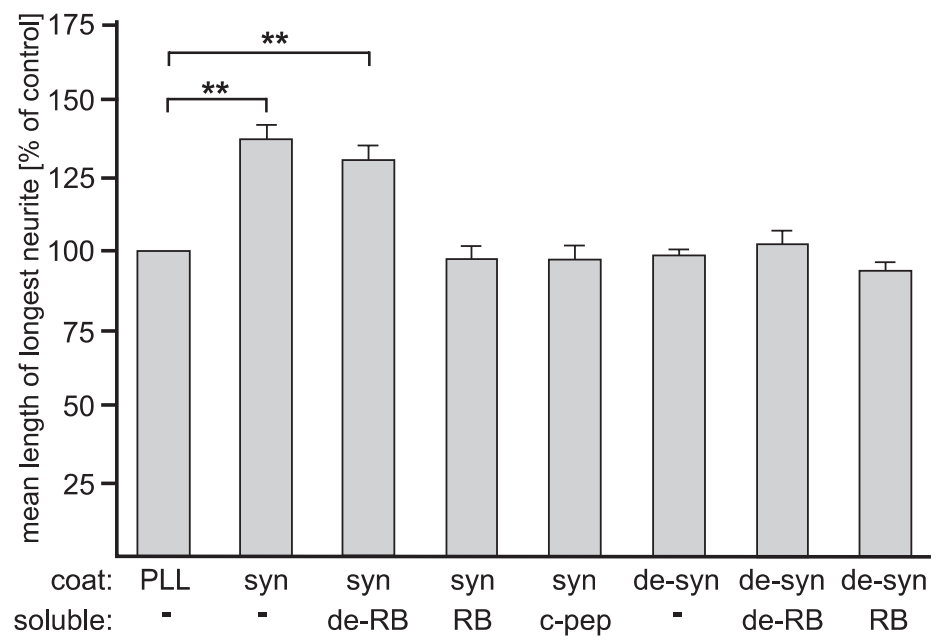

Figure 7. Glia-derived synapsin promotes neurite outgrowth in an oligomannose-dependent manner. $\boldsymbol{A}$, Hippocampal neurons were grown on substrate-coated PLL or synapsin (syn) in the absence (-) or presence of soluble synapsin. After fixation, the length of the longest neurite per cell was determined and value obtained with PLL coat in the absence of soluble synapsin was set to $100 \%$. B-D, Wild-type (WT) hippocampal neurons were plated on mature wild-type or synapsin TK0 glial cultures, maintained for $24 \mathrm{~h}$, fixed, and stained with antibodies against neurofilament heavy chain and $\beta$-III tubulin to identify axons and the neurite network, respectively. $\boldsymbol{B}$, Representative images of wild-type hippocampal neurons maintained on wild-type (top) or synapsin TKO glia (bottom). Scale bar, $10 \mu \mathrm{m}$. C, WT neurons grown on TK0 glia show a simpler neurite network than neurons grown in parallel on WT glia. Sholl analysis was performed on $n=225$ cells per genotype, from three independent experiments. The number of intersections (means $\pm S E M$ ) is plotted as function of the distance from the cell body $\left({ }^{* * *} p<0.001\right.$, Mann-Whitney $U$ test). $D$, The average axonal length and the average number of axonal branching of wild-type (WT) hippocampal neurons maintained on either WT or synapsin TKO glia was determined and compared. Axons were identified as processes that were positive for neurofilament heavy chain immunostaining, and manually measured. $n=60$ cells per genotype, from two independent experiments ( ${ }^{* *} p<0.01$, ${ }^{* * *} p<0.001$, Mann-Whitney U test). E, Hippocampal neurons were grown on substrate-coated PLL alone (-), synapsin (syn), or EndoH-treated synapsin (de-syn) in the absence ( - ) or presence of untreated RNase $B(R B)$, deglycosylated RNase $B$ (de-RB), or catalase-coupled oligomannose-mimicking peptide (c-pep). The length of the longest neurite per cell was determined and the mean length of the longest neurites obtained with PLL coat was set to $100 \%$. $\boldsymbol{A}, \boldsymbol{E}$, Mean values \pm SEM of three independent experiments are shown $\left({ }^{*} p<0.05\right.$; one-way ANOVA followed by Dunnett's multiple-comparison test).

characterized by coimmunostaining with antibodies against synapsin and the neuronal marker $\beta$-III tubulin or the astrocytic marker GFAP. As expected, the vast majority of cells (61.5 \pm $11.2 \%$ ) showed the typical flattened morphology of protoplasmic astrocytes and were intensely stained by GFAP (Fig. 9A). GFAPpositive astrocytes displayed a relatively weak synapsin staining, while a significant number of GFAP-negative cells $(21.4 \pm 8.3 \%)$ showed a strong synapsin staining (Fig. 9A). A very small number of cells $(2.2 \pm 1.1 \%)$ displayed neuronal features and were strongly positive for both $\beta$-III tubulin and synapsin (Fig. 9B). Quantification of the synapsin staining intensity in neurons and glial cells (Fig. 9C) revealed that synapsin immunoreactivity in neurons was fourfold to fivefold higher than that of glial cells. The contribution of autofluorescence or nonspecific background staining was ruled out by omitting primary antibodies and by using a Cy3-labeled instead of a Cy2-labeled secondary antibody for the detection of synapsin (data not shown). In addition, astrocyte-enriched cultures from wild-type and TKO mice were stained with GFAP and synapsin antibodies. A weak synapsin immunoreactivity was seen in GFAP-positive wild-type astrocytes, but not in TKO astrocytes (Fig. 9D). These results demonstrate that the staining by the synapsin antibody was specific. Interestingly, a number of cells $(14.3 \pm 4.1 \%)$ not resembling neurons or protoplasmic astrocytes showed no detectable staining of $\beta$-III tubulin, but a pronounced synapsin staining (Fig. $9 B)$. To analyze whether these $\beta$-III tubulin- and GFAP-negative 
A
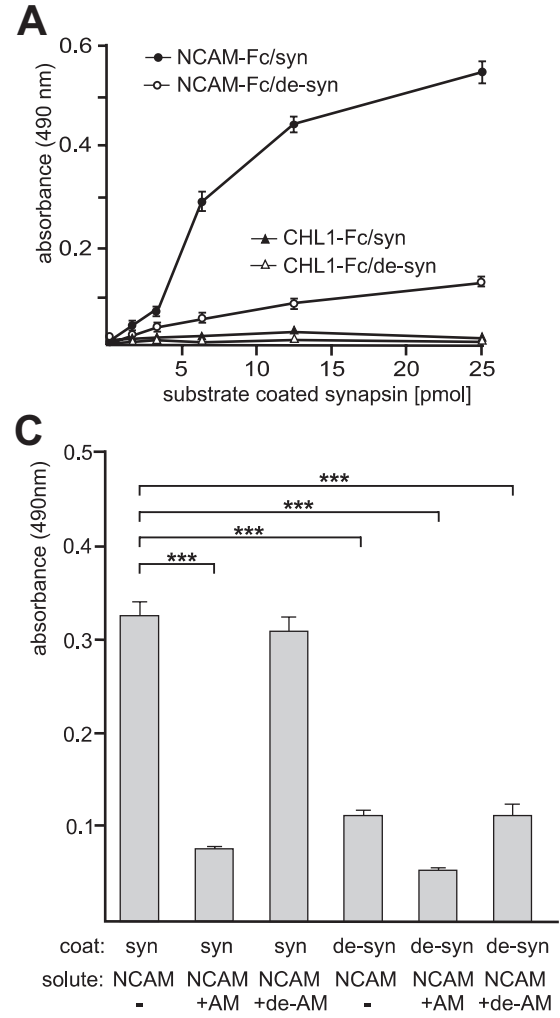

B

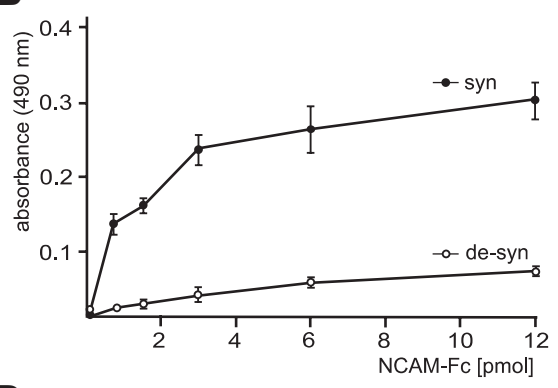

D

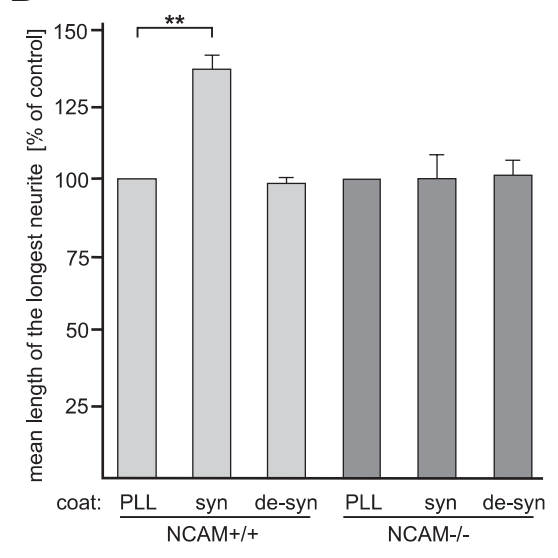

Figure 8. Synapsin binds to the extracellular domain of NCAM in an oligomannose-dependent manner and promotes neurite outgrowth in an NCAM-dependent manner. $\boldsymbol{A}$, Increasing amounts of either untreated (syn) or EndoH-treated (de-syn) synapsin were substrate coated and incubated with either NCAM-Fc or CHL1-Fc. B, Substrate-coated untreated (syn) or EndoH-treated (de-syn) synapsin was incubated with increasing amounts of NCAM-Fc. C, Synapsin (syn) or synapsin treated with EndoH (de-syn) was substrate coated and incubated in the absence or presence of NCAM-FC (NCAM), NCAM-Fc preincubated with AMOG (NCAM + AM), or NCAM preincubated with EndoH-deglycosylated AMOG (NCAM + de-AM). A-C, The binding of NCAM-FC or CHL1 was determined by ELISA using a human Fc antibody. Mean values \pm SEM of three independent experiments are shown $\left({ }^{*} p<\right.$ $0.05,{ }^{* *} p<0.01,{ }^{* * *} p<0.001$ one-way ANOVA followed by Dunnett's multiple-comparison test). $\boldsymbol{D}$, Hippocampal neurons of NCAM-deficient (NCAM-/-) and wild-type (NCAM $+/+$ ) mice were grown on substrate-coated untreated (syn) or EndoHtreated (de-syn) synapsin. After $24 \mathrm{~h}$ in culture, cells were fixed and stained, and the length of the longest neurite per cell was determined. Mean length of the longest neurites obtained on PLL was set to $100 \%$. Mean values \pm SEM of two independent experiments are shown ${ }^{* *} p<0.01$ one-way ANOVA followed by Dunnett's multiple-comparison test).

cells were microglia, oligodendrocytes, or NG2-glia, which represent a glial cell type distinct from astrocytes, microglia, and oligodendrocytes [for review, see Trotter et al. (2010), Wigley and Butt (2009), and Bergles et al. (2010)], we performed double immunostaining with an antibody to synapsin and antibodies to the microglial marker Iba-1, the oligodendrocyte marker myelin basic protein, and the NG2-glia marker NG2. Cells with a specific Iba-1 or myelin basic protein immunoreactivity were not observed in our cell culture (data not shown), while a remarkable number of cells $(10.6 \pm 2.2 \%)$ showed strong immunoreactivity for both synapsin and NG2 (Fig. 9E). In an astrocyte-enriched cell culture from cortex, a similar percentage of total cells (11.3 \pm $3.3 \%$ ) were positive for NG2 staining and the NG2-positive cell showed a pronounced synapsin staining in comparison to the weak synapsin staining of NG2-negative cells (Fig. 9F). The mean area intensity of NG2-positive cells was determined to be twofold to threefold higher than that measured for NG2-negative cells. These results indicate that NG2-positive glial cells express synapsin, while GFAP-positive astrocytes express much smaller amounts of synapsin. Thus, it is possible that synapsin is released only by NG2-positive glia and not by astrocytes. On the other hand, it is also possible that astrocytes release synapsin and thus, show only a weak staining for synapsin, while NG2-glia express but do not release synapsin.

\section{Discussion \\ Synapsin is an oligomannose-bearing glycoprotein and oligomannose- recognizing lectin}

To gain further insights into the functions of oligomannoses in the nervous system, we tried to identify new oligomannosecarrying proteins and oligomannosebinding lectin-like proteins and identified synapsin as an oligomannose-binding and oligomannose-carrying protein. Both synapsin Ia and synapsin Ib, the two splice variants of the synapsin I gene, have been shown to carry fucose- $\alpha 1,2$-galactose on O-glycans (Murrey et al., 2006). Here, we showed that synapsin I carries Lewis ${ }^{\mathrm{x}}$ also on O-glycans and oligomannoses on $N$-glycans. Synapsin Ia carries an $\mathrm{N}$-linked glycosylation site at the very beginning of the E domain, which plays a fundamental role in synapsin function (Hilfiker et al., 1998; Fassio et al., 2006), and it is thus possible that only this synapsin isoform carries the $\mathrm{N}$-linked oligomannoses.

Since synapsin occurs as a glycoprotein and since glycosylation is a characteristic posttranslational modification of extracellular proteins, our findings are consistent with the idea that synapsin may be secreted as extracellular glycoprotein. The route by which cytoplasmic synapsin is glycosylated and the secretion pathway of synapsin in glia cells are not known. The observation of an interaction between synapsin and the glycosyl phosphatidyl inositol-linked prion protein (Spielhaupter and Schätzl, 2001) also suggest that synapsin may act as an extracellular protein and interact with cell surface receptors. Here, we provide evidence that recognition of oligomannose on synapsin by NCAM triggers synapsin-dependent neurite outgrowth. In addition, since we found that synapsin also binds to oligomannoses on AMOG, which is exclusively present on astrocytes, it is possible that this interaction triggers biological responses in astrocytes.

\section{Possible role of synapsin in neural cell interactions}

Glia-neuron interactions, which can be modulated by carbohydrates, play a critical role in brain development and function. Here, we showed that oligomannose-mimicking peptides or oligomannose-carrying RNase B inhibit adhesion between cerebellar neurons and glial cells. These results indicate that glianeuron interactions depend, at least partially, on oligomannoses. In the present study, we demonstrate that cultured glial cells express synapsin and release it via exosomes into the extracellular space. Cell surface biotinylation indicated that a significant portion of this extracellular synapsin is present as a cell surfaceassociated molecule, supporting its possible role in mediating and/or modulating glia-neuron interactions. We failed to dem- 
onstrate synapsin at the cell surface of astrocytes by immunostaining, possibly because synapsin on live glial cells is not accessible to the antibody or the number or density of synapsin molecules at the cell surface is too low to be detectable by immunostaining. So far, synapsin has been detected by immunohistological methods only in neuronal cells, while nonneuronal cells did not show detectable staining of synapsin (De Camilli et al., 1983). However, one cannot exclude the possibility that synapsin is also expressed in vivo in non-neuronal cells, because detection by immunostaining depends on specificity and sensitivity of antibodies, quantity and accessibility of antigens, and other experimental constraints. In our in vitro experiments, we also showed that GFAP-positive astrocytes in culture were scarcely positive for synapsin staining. However, we observed strong synapsin immunoreactivity on NG2-expressing cells, which represent a distinct subpopulation of glial cells that form contacts with astrocytes and neurons [for review, see Wigley and Butt (2009), Bergles et al. (2010), and Trotter et al. (2010)]. The functions of NG2-expressing cells, which are also called synantocytes or polydendrocytes, are unknown. Since we observed an intense staining of synapsin in NG2-positive glial cells, it is possible that only NG2-expressing glial cells express and release synapsin. Another explanation is that these glial cells do not release, but accumulate, synapsin and, thus, are strongly synapsin immunopositive. On the other hand, we cannot exclude the possibility that the glial cells that are only weakly synapsin immunopositive release synapsin via exosomes and thus, showed a weak immunostaining. Since we obtained no indications that cultured neurons release synapsin, we exclude the possibility that the release of synapsin via exosomes in glia-enriched cell cultures is due to the presence of only a few neurons in glial cell cultures.

\section{Extracellular synapsin is released by glia-derived exosomes}

For glia-neuron communication, not only direct cell-to-cell contact but also the exchange of soluble factors appears to be important. Exosomes have been suggested to be involved in these intercellular communications and intercellular protein transport [for review, see Simons and Raposo (2009)]. In the present study, we found that exosomes released from glial cells carry synapsin, and we observed in in vitro experiments that synapsin was released from isolated exosomes in the presence of 75-80 $\mathrm{mm} \mathrm{KCl}$, while other cargo proteins, such as actin or hsc70, are not released. The selective release of synapsin from glial-derived exosomes under distinct conditions suggests a regulated release mechanism for synapsin at high $\mathrm{KCl}$ concentrations. In vivo, it may be possible that synapsin is released from exosomes by a more moderate increase in $\mathrm{KCl}$ concentrations and/or by other factors, such as the extracellular calcium and magnesium concentrations. Indeed, the release of synapsin from exosomes was inhibited in vitro in the presence of $1.5 \mathrm{mM} \mathrm{MgCl} / \mathrm{CaCl}_{2}$, and thus, low extracellular magnesium and calcium concentrations may be a prerequisite for the release of synapsin from exosomes under in
B
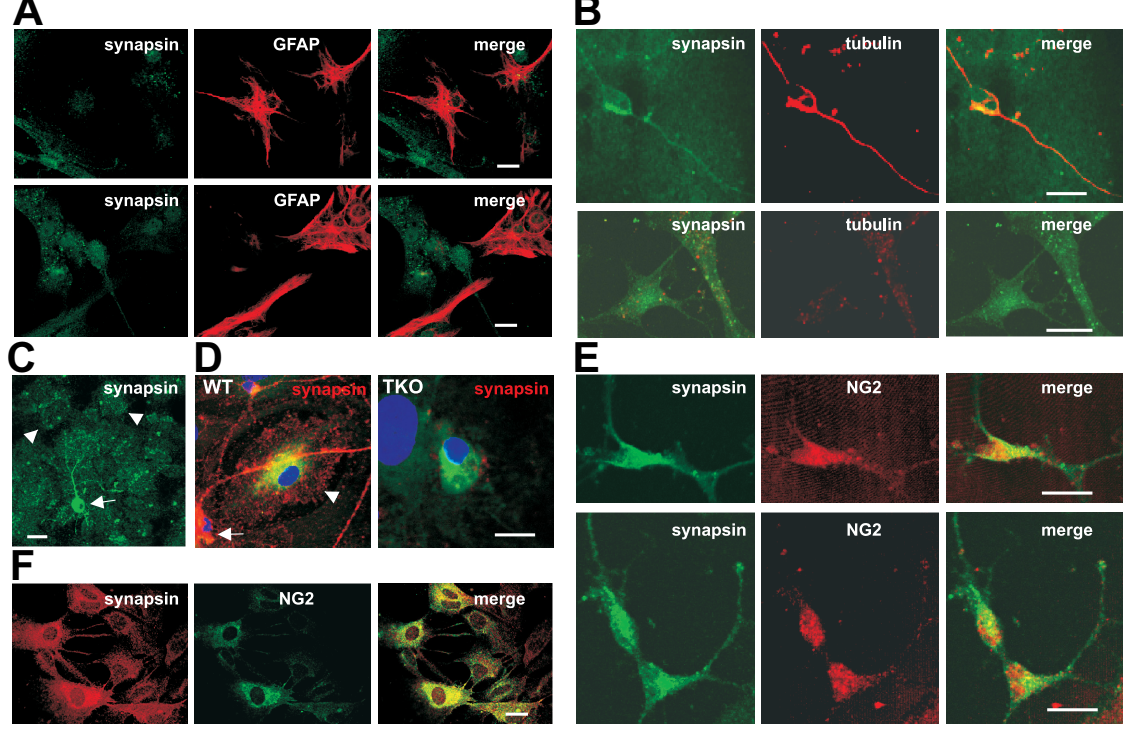

Figure 9. Synapsin is expressed by glial cells. $\boldsymbol{A}-\boldsymbol{E}$, Upon fixation and permeabilization, astrocyte-enriched glial cell cultures from whole brain of wild-type mice $(\boldsymbol{A}-\boldsymbol{C}, \boldsymbol{E})$ or cortex of wild-type $(\boldsymbol{D}, \boldsymbol{F})$ or TKO $(\boldsymbol{D})$ mice were subjected to double immunostaining a mouse synapsin antibody and rabbit $\operatorname{GFAP}(\boldsymbol{A}, \boldsymbol{D}), \beta$-III tubulin $(\boldsymbol{B})$, or NG2 $(\boldsymbol{E}, \boldsymbol{F})$ antibodies. Secondary anti-mouse synapsin ${ }^{+}$neuron-like cell ( $\boldsymbol{B}$, top) and tubulin ${ }^{-}$/synapsin ${ }^{+}$cells $\left(\boldsymbol{B}\right.$, bottom), synapsin ${ }^{+}$neurons $(\boldsymbol{C}$, arrow) and surrounding well as in a neuronal cell body (arrow) and along neurites (left), while no synapsin immunoreactivity is detectable in a GFAP ${ }^{+}$TKO astrocytes (right). $\boldsymbol{A}-\boldsymbol{F}$, Scale bars, $50 \mu \mathrm{m}$.

vivo conditions. In the intact nervous tissue, transient elevations of up to $80 \mathrm{~mm} \mathrm{KCl}$ are observed during propagation of SD waves (for review, see Irwin and Walz, 1999). SD waves have been observed in the normal and diseased or injured brain under pathological conditions, such as focal ischemia/stroke or migraine [for review, see Irwin and Walz (1999) and Lauritzen et al. (2011)]. Interestingly, the extracellular levels of magnesium and calcium change in association with pathological stress conditions such as ischemia or hypoglycemia and low extracellular calcium and magnesium concentrations have been implicated in seizures and migraine and have been shown to evoke calcium waves that resemble those observed during SD (Stout and Charles, 2003, and references therein). SD waves in healthy brains lead to activation of microglia and astrocytes, which can secrete neurotrophic factors, exert neuroprotective functions, and play beneficial roles in preischemic conditioning, making the tissue more resistant to subsequent insults. Interestingly, hypoxia or ischemia has been shown to result in an increase of synapsin levels in various brain regions (Ploughman et al., 2005), suggesting that synapsin is involved in the brain's response to stress conditions and that it is associated with neuroprotective mechanisms. One may speculate that $\mathrm{SD}$ waves or oxidative stress lead to increases in extracellular $\mathrm{KCl}$ concentrations, which trigger the release of synapsin from glia-derived exosomes.

\section{Extracellular synapsin stimulates neurite outgrowth and is neuroprotective}

Several reports indirectly indicate that synapsins modulate neuronal development through the promotion of neurite outgrowth and synaptogenesis. The expression pattern of synapsin closely parallels the dynamics of neuropil development and synapse formation, thus suggesting a functional link between the onset of 
synapsin expression and the maturation of the neuronal network (Fornasiero et al., 2010). Lack of synapsin was reported to cause a general growth impairment of hippocampal neurons in in vitro culture during the first days, but no longer at later stages (Chin et al., 1995). Since synapsins are actin-binding proteins and interact with multiple cytoskeletal proteins (Cesca et al., 2010), it is currently believed that the synapsin effects on neuronal development are mainly attributable to a regulation of actin cytoskeleton dynamics. Our study indicates that glial-derived synapsin when released into the extracellular space may contribute to the synapsin's effects on neuronal development.

Moreover, our results show that, when applied extracellularly, synapsin is neuroprotective under stress conditions. Interestingly, it has been shown that aged synapsin I-deficient mice display an increased loss of neurons in the neocortex and hippocampus (Corradi et al., 2008) and that stress-related memory induced by a glucocorticoid-triggered signaling pathway is synapsin dependent (Revest et al., 2010), indicating an important function of synapsin for neuronal survival following exposure to stress.

In summary, results from our study provide evidence that, in the nervous system, glia-derived exosomes and glia-derived synapsin released into the extracellular space represent a means to provide particular cargo proteins, such as synapsin. In turn, these cargo proteins may modulate glia-neuron interactions and communication as well as serve neuroprotective functions.

\section{References}

Antonicek H, Schachner M (1988) The adhesion molecule on glia (AMOG) incorporated into lipid vesicles binds to subpopulations of neurons. J Neurosci 8:2961-2966.

Bähler M, Greengard P (1987) Synapsin I bundles F-actin in a phosphorylation-dependent manner. Nature 326:704-707.

Bergles DE, Jabs R, Steinhäuser C (2010) Neuron-glia synapses in the brain. Brain Res Rev 63:130-137.

Bustos R, Kolen ER, Braiterman L, Baines AJ, Gorelick FS, Hubbard AL (2001) Synapsin I is expressed in epithelial cells: localization to a unique trans-Golgi compartment. J Cell Sci 114:3695-3704.

Candiani S, Moronti L, Pennati R, De Bernardi F, Benfenati F, Pestarino M (2010) The synapsin gene family in basal chordates: evolutionary perspectives in metazoans. BMC Evol Biol 10:32.

Cesca F, Baldelli P, Valtorta F, Benfenati F (2010) The synapsins: key actors of synapse function and plasticity. Prog Neurobiol 91:313-348.

Chandrasekaran S, Dean JW 3rd, Giniger MS, Tanzer ML (1991) Laminin carbohydrates are implicated in cell signaling. J Cell Biochem 46:115-124.

Chen S, Mantei N, Dong L, Schachner M (1999) Prevention of neuronal cell death by neural adhesion molecules L1 and CHL1. J Neurobiol 38:428-439.

Chin LS, Li L, Ferreira A, Kosik KS, Greengard P (1995) Impairment of axonal development and of synaptogenesis in hippocampal neurons of synapsin I-deficient mice. Proc Natl Acad Sci U S A 92:9230-9234.

Corradi A, Zanardi A, Giacomini C, Onofri F, Valtorta F, Zoli M, Benfenati F (2008) Synapsin-I- and synapsin-II-null mice display an increased agedependent cognitive impairment. J Cell Sci 121:3042-3051.

Cremer H, Lange R, Christoph A, Plomann M, Vopper G, Roes J, Brown R, Baldwin S, Kraemer P, Scheff S, Barthels D, Rajewsky K, Wille W (1994) Inactivation of the $\mathrm{N}$-CAM gene in mice results in size reduction of the olfactory bulb and deficits in spatial learning. Nature 367:455-459.

De Camilli P, Cameron R, Greengard P (1983) Synapsin I (protein I), a nerve terminal-specific phosphoprotein. I. Its general distribution in synapses of the central and peripheral nervous system demonstrated by immunofluorescence in frozen and plastic sections. J Cell Biol 96:1337-1354.

Fahrig T, Schmitz B, Weber D, Kücherer-Ehret A, Faissner A, Schachner M (1990) Two monoclonal antibodies recognizing carbohydrate epitopes on neural adhesion molecules interfere with cell interactions. Eur J Neurosci 2:153-161.

Fassio A, Merlo D, Mapelli J, Menegon A, Corradi A, Mete M, Zappettini S, Bonanno G, Valtorta F, D’Angelo E, Benfenati F (2006) The synapsin domain $\mathrm{E}$ accelerates the exoendocytotic cycle of synaptic vesicles in cerebellar Purkinje cells. J Cell Sci 119:4257-4268.
Fornasiero EF, Bonanomi D, Benfenati F, Valtorta F (2010) The role of synapsins in neuronal development. Cell Mol Life Sci 67:1383-1396.

Fu SC, Gurd JW (1983) Developmental changes in the oligosaccharide composition of synaptic junctional glycoproteins. J Neurochem 41:1726-1734.

Gitler D, Takagishi Y, Feng J, Ren Y, Rodriguiz RM, Wetsel WC, Greengard P, Augustine GJ (2004) Different presynaptic roles of synapsins at excitatory and inhibitory synapses. J Neurosci 24:11368-11380.

Heiland PC, Griffith LS, Lange R, Schachner M, Hertlein B, Traub O, Schmitz B (1998) Tyrosine and serine phosphorylation of the neural cell adhesion molecule L1 is implicated in its oligomannosidic glycan dependent association with NCAM and neurite outgrowth. Eur J Cell Biol 75:97-106.

Heller M, von der Ohe M, Kleene R, Mohajeri MH, Schachner M (2003) The immunoglobulin-superfamily molecule basigin is a binding protein for oligomannosidic carbohydrates: an anti-idiotypic approach. J Neurochem 84:557-565.

Hilfiker S, Schweizer FE, Kao HT, Czernik AJ, Greengard P, Augustine GJ (1998) Two sites of action for synapsin domain $E$ in regulating neurotransmitter release. Nat Neurosci 1:29-35.

Horstkorte R, Schachner M, Magyar JP, Vorherr T, Schmitz B (1993) The fourth immunoglobulin-like domain of NCAM contains a carbohydrate recognition domain for oligomannosidic glycans implicated in association with L1 and neurite outgrowth. J Cell Biol 121:1409-1421.

Husmann K, Faissner A, Schachner M (1992) Tenascin promotes cerebellar granule cell migration and neurite outgrowth by different domains in the fibronectin type III repeats. J Cell Biol 116:1475-1486.

Irwin A, Walz W (1999) Spreading depression waves as mediators of secondary injury and of protective mechanisms. In: Cerebral ischemia (Walz W, ed), pp 35-44 Totowa, NJ: Humana.

Johnson MA, Rotondo A, Pinto BM (2002) NMR studies of the antibodybound conformation of a carbohydrate-mimetic peptide. Biochemistry 41:2149-2157.

Kaech S, Banker G (2006) Culturing hippocampal neurons. Nat Protoc 1:2406-2415.

Kao HT, Porton B, Hilfiker S, Stefani G, Pieribone VA, DeSalle R, Greengard P (1999) Molecular evolution of the synapsin gene family. J Exp Zool 285:360-377.

Kleene R, Schachner M (2004) Glycans and neural cell interactions. Nat Rev Neurosci 5:195-208.

Kleene R, Loers G, Langer J, Frobert Y, Buck F, Schachner M (2007) Prion protein regulates glutamate-dependent lactate transport of astrocytes. J Neurosci 27:12331-12340.

Krueger KA, Ings EI, Brun AM, Landt M, Easom RA (1999) Site-specific phosphorylation of synapsin I by $\mathrm{Ca}^{2+} /$ calmodulin-dependent protein kinase II in pancreatic betaTC3 cells: synapsin I is not associated with insulin secretory granules. Diabetes 48:499-506.

Kücherer A, Faissner A, Schachner M (1987) The novel carbohydrate epitope L3 is shared by some neural cell adhesion molecules. J Cell Biol 104:1597-1602.

Lakkaraju A, Rodriguez-Boulan E (2008) Itinerant exosomes: emerging roles in cell and tissue polarity. Trends Cell Biol 18:199-209.

Lauritzen M, Dreier JP, Fabricius M, Hartings JA, Graf R, Strong AJ (2011) Clinical relevance of cortical spreading depression in neurological disorders: migraine, malignant stroke, subarachnoid and intracranial hemorrhage, and traumatic brain injury. J Cereb Blood Flow Metab 31:17-35.

Lüthl A, Laurent JP, Figurov A, Muller D, Schachner M (1994) Hippocampal long-term potentiation and neural cell adhesion molecules L1 and NCAM. Nature 372:777-779.

Maienschein V, Marxen M, Volknandt W, Zimmermann H (1999) A plethora of presynaptic proteins associated with ATP-storing organelles in cultured astrocytes. Glia 26:233-244.

Matsumoto K, Fukunaga K, Miyazaki J, Shichiri M, Miyamoto E (1995) $\mathrm{Ca}^{2+} /$ calmodulin-dependent protein kinase II and synapsin I-like protein in mouse insulinoma MIN6 cells. Endocrinology 136:3784-3793.

Monzavi-Karbassi B, Cunto-Amesty G, Luo P, Kieber-Emmons T (2002) Peptide mimotopes as surrogate antigens of carbohydrates in vaccine discovery. Trends Biotechnol 20:207-214.

Murrey HE, Gama CI, Kalovidouris SA, Luo WI, Driggers EM, Porton B, Hsieh-Wilson LC (2006) Protein fucosylation regulates synapsin Ia/Ib expression and neuronal morphology in primary hippocampal neurons. Proc Natl Acad Sci U S A 103:21-26.

Pirofski LA (2001) Polysaccharides, mimotopes and vaccines for fungal and encapsulated pathogens. Trends Microbiol 9:445-451. 
Ploughman M, Granter-Button S, Chernenko G, Tucker BA, Mearow KM, Corbett D (2005) Endurance exercise regimens induce differential effects on brain-derived neurotrophic factor, synapsin-I and insulin-like growth factor I after focal ischemia. Neuroscience 136:991-1001.

Revest JM, Kaouane N, Mondin M, Le Roux A, Rougé-Pont F, Vallée M, Barik J, Tronche F, Desmedt A, Piazza PV (2010) The enhancement of stressrelated memory by glucocorticoids depends on synapsin-Ia/Ib. Mol Psychiatry 15:1140-1151.

Romano C, Nichols RA, Greengard P, Greene LA (1987) Synapsin I in PC12 cells. I. Characterization of the phosphoprotein and effect of chronic NGF treatment. J Neurosci 7:1294-1299.

Schmid RS, Graff RD, Schaller MD, Chen S, Schachner M, Hemperly JJ, Maness PF (1999) NCAM stimulates the Ras-MAPK pathway and CREB phosphorylation in neuronal cells. J Neurobiol 38:542-558.

Schmidt JT, Schachner M (1998) Role for cell adhesion and glycosyl (HNK-1 and oligomannoside) recognition in the sharpening of the regenerating retinotectal projection in goldfish. J Neurobiol 37:659-671.

Simon-Haldi M, Mantei N, Franke J, Voshol H, Schachner M (2002) Identification of a peptide mimic of the L2/HNK-1 carbohydrate epitope. J Neurochem 83:1380-1388.
Simons M, Raposo G (2009) Exosomes-vesicular carriers for intercellular communication. Curr Opin Cell Biol 21:575-581.

Simpson RJ, Jensen SS, Lim JW (2008) Proteomic profiling of exosomes: current perspectives. Proteomics 8:4083-4099.

Spielhaupter C, Schätzl HM (2001) PrPC directly interacts with proteins involved in signaling pathways. J Biol Chem 276:44604-44612.

Stout C, Charles A (2003) Modulation of intercellular calcium signaling in astrocytes by extracellular calcium and magnesium. Glia 43:265-273.

Tanzer ML, Giniger MS, Chandrasekaran S (1993) Laminin oligosaccharides play a pivotal role in cell spreading. Symp Soc Exp Biol 47:147-154.

Tooze J, Hollinshead M, Fuller SD, Tooze SA, Huttner WB (1989) Morphological and biochemical evidence showing neuronal properties in AtT-20 cells and their growth cones. Eur J Cell Biol 49:259-273.

Trotter J, Karram K, Nishiyama A (2010) NG2 cells: properties, progeny and origin. Brain Res Rev 63:72-82.

Wigley R, Butt AM (2009) Integration of NG2-glia (synantocytes) into the neuroglial network. Neuron Glia Biol 5:21-28.

Won CL, Oh YS (2000) cAMP-induced stellation in primary astrocyte cultures with regional heterogeneity. Brain Res 887:250-258. 